College of William \& Mary Law School William \& Mary Law School Scholarship Repository

1965

\title{
The Fourteenth Amendment, the "Right" to Vote, and the Understanding of the Thirty-Ninth Congress
}

William W. Van Alstyne

William \& Mary Law School

\section{Repository Citation}

Van Alstyne, William W., "The Fourteenth Amendment, the "Right" to Vote, and the Understanding of the Thirty-Ninth Congress" (1965). Faculty Publications. 779.

https://scholarship.law.wm.edu/facpubs/779

Copyright c 1965 by the authors. This article is brought to you by the William \& Mary Law School Scholarship Repository. https://scholarship.law.wm.edu/facpubs 
WILLIAM W. VAN ALSTYNE

\author{
THE FOURTEENTH AMENDMENT,
}

THE "RIGHT" TO VOTE, AND

THE UNDERSTANDING OF THE

THIRTY-NINTH CONGRESS

"If that history does not prove what I think it does, we are at least entitled to be told why." "The request is that of Mr. Justice Harlan, dissenting in Carrington v. Rash, ${ }^{1}$ which held that a Texas constitutional provision preventing a citizen who had entered military service in another state from acquiring voting residence in Texas so long as he remained in the military denies equal protection. ${ }^{2}$ The

William W. Van Alstyne is Professor of Law, Duke University.

1380 U.S. 89, 97 (1965).

2 The petitioner had entered the Army in Alabama in 1946, at the age of 18, and had resided in Texas since 1962, where he intended to remain permanently. He owned a home in El Paso, Texas, where he lived with his wife and two children. He also operated a small business in El Paso and paid property taxes in Texas. "But for his uniform, the State concede[d] that the petitioner would be eligible to vote in El Paso County, Texas." Id. at 91 . The Court did not determine, as it might have done, that the Texas provision specially disabling servicemen otherwise qualified to vote was invalid under Article VI, cl. 2 (the Supremacy Clause), by construing the federal statute under which the petitioner served in the military to forbid sucl discrimination. The statute itself was a valid exercise of congressional power under Article I, $\S 8$, cl. 12 , "to raise and support Armies," and related sections relevant to government of the military. Nor did it touch upon the possible relevance of Article IV, $\$ 2$ "The Citizens of each State shall be entitled to all Privileges and Immunities of Citizens in the several States"), by characterizing the Texas provision as unreasonably dis- 
"history" to which Mr. Justice Harlan referred is the legislative history of the Fourteenth Amendment. What he believes that history proves is that the Fourteenth Amendment, and especially $\S 2$, "expressly recognizes the States' power to deny 'or in any way' abridge the right of their inhabitants to vote for 'the members of the [state] Legislature." "3 As a consequence, all complaints arising only under the Equal Protection Clause and directed against alleged invidious discrimination affecting the right to vote should be dismissed "for failure to state a claim of federal right."

Mr. Justice Harlan's dissent in Carrington v. Rash preserves the position he took in the reapportionment cases, that complaints under the Equal Protection Clause of partial disfranchisement resulting from malapportioned state legislative districts "should all have been dismissed ... for failure to state a cause of action, because what has been alleged or proved shows no violation of any constitutional right." " His position respecting the irrelevance of equal protection to state suffrage issues was consistently maintained last Term in three other cases, in addition to Carrington $v$. Rash. In two of these he emphasized that however vulnerable to constitutional challenge the so-called literacy tests of Mississippi and Louisiana may be under the Fifteenth Amendment, they are not vulnerable under the Fourteenth Amendment. ${ }^{6}$ In the third, he agreed that a Virginia poll tax scheme that imposed unnecessary burdens on qualified voters in federal elections violated the Twenty-fourth Amendment, but he carefully disavowed dicta in the Court's opinion that the state

criminating against a class of persons because of their original status as citizens of other states. The holding of the case was based exclusively on the Equal Protection Clause of the Fourteenth Amendment.

3 Reynolds v. Sims, 377 U.S. 533, 589, 594 (1964) (Harlan, J., dissenting).

4380 U.S. at $97,99$.

5 Reynolds v. Sims, 377 U.S. 533, 589, 591-92 (1964). See also WMCA, Inc. v. Lomenzo, 377 U.S. 633, 655 (1964); Maryland Committee for Fair Representation v. Tawes, 377 U.S. 656, 676 (1964); Davis v. Mann, 377 U.S. 678, 693 (1964); Roman v. Sincock, 377 U.S. 695, 712 (1964); Lucas v. Forty-fourth General Assembly of Colorado, 377 U.S. 713, 741 (1964); Wesberry v. Sanders, 376 U.S. 1, 20 (1964); Baker v. Carr, 369 U.S. 186, 266, 330 (1962); Gray v. Sanders, 372 U.S. 368, 382 (1963).

6 United States v. Mississippi, 380 U.S. 128, 144 (1965); Louisiana v. United States, 380 U.S. 145, 156 (1965). 
statute in question may also have been subject to challenge under the Fourteenth Amendment. ${ }^{7}$

The persistence with which Mr. Justice Harlan has maintained his position is completely understandable. In his dissent of 1964 , in Reynolds $v$. Sims, he devoted forty-two pages to a comprehensive legislative history of $\S 2$ of the Fourteenth Amendment. Almost all of it was consistent only with the conclusion he derived from it. Neither in that case nor in any of the other reapportionment cases did any member of the Court fault Mr. Justice Harlan's historical presentation. Nor did they undertake to demonstrate in what respect, if any, it was irrelevant to the issues at hand. Nearly a year and several similar cases later, when Mr. Justice Harlan chided the

$\tau$ Harman v. Forssenius, 380 U.S. 528, 544 (1965). It should be noted that these are not the first cases to have reviewed voter qualifications under the Equal Protection Clause. In Lassiter v. Northampton County Bd. of Elections, 360 U.S. 45 (1959), a North Carolina literacy qualification was examined on the merits of a claim that, on its face, it denied equal protection. The test was upheld, although the Court applied a mere "rational nexus" test in finding the test sufficiently related to a permissible policy of promoting intelligent use of the ballot. No argument appears to have been made that the test might be discriminatory as applied to Negroes disadvantaged from being obliged to attend inferior, segregated schools, resulting in a lower incidence of literacy attributable to state action. In Breedlove v. Suttles, 302 U.S. 277 (1937), a poll tax payment qualification was examined on the merits of a claim that it denied equal protection because of exemptions provided for certain classes. The requirement was upheld under a rational nexus test. No argument based on the Fifteenth Amendment, or on a theory of unwarranted discrimination under the Fourteenth Amendment, appears to have been made. Cf. Griffin v. Illinois, 351 U.S. 12 (1956). The case does not dictate the result recently reached in Harper v. Virginia Board of Election, 240 F. Supp. 270 (E.D. Va., 1964), prob. juris. noted, 380 U.S. 930 (1965). In Nixon v. Condon, 286 U.S. 70 (1932), the Court invalidated a Denocratic party qualification restricting primary election voters to wbites only, relying solely on the Equal Protection Clause. In Nixon v. Herndon, 273 U.S. 536 (1927), the Court unanimously invalidated a state qualification restricting party primaries to whites only, relying solely on the Equal Protection Clause. Cf. Mr. Justice Harlan's explanation of the two Nixon cases in Reynolds. 377 U.S. at 614-15 n. 72. In Williams v. Mississippi, 170 U.S. 213 (1898), literacy, residency, poll tax, and morality qualificatious were examined on the merits of an equal protection claim and upheld on their face as not discriminatory against Negroes. In declaring that the qualifications "reach weak and vicious white men as well as weak and vicious black men," $i d$. at 222 , the Court found that the qualifications were consistent with equal protection as understood at that time, rather than that the Equal Protection Clause provided no basis for review. Minor v. Happersett, 21 Wall. 162 (1874), was argued and decided exclusively on the basis of the Privileges and Immunities Clause. No equal protection claim was asserted. Compare, with these cases, the dicta in Pope v. Williams, 193 U.S. 621, 632-33 (1904); Guinn v. United States, 238 U.S. 347, 362 (1915). 
Court in Carrington v. Rash for its telling silence, there was still no explanation forthcoming. Given ample opportunity either to refute Mr. Justice Harlan's historical review, or to demonstrate its irrelevance to the issues at hand, the majority seems tacitly to have conceded the argument, if not the vote. Nor is this clearly an issue sufficient for the Court to say that we cannot turn back the clock. The right to vote probably cannot be shown to be of greater importance to the individual in 1965 than it was in 1866, when the Fourteenth Amendment was approved by Congress. The varieties and degrees of disfranchisement probably cannot be shown to be much greater or more serious than, or different from, those current in $1866 . .^{\circ}$ Nor can it be shown that the arguable relevance of the Fourteenth Amendment to state electoral matters was overlooked or submerged during active consideration of that Amendment. To the contrary, a review of Mr. Justice Harlan's dissent in Reynolds v. Sims suggests that the "right" to vote was the single most deliberately considered subject of the time and that the provision made in $\S 2$ of the Amendment was intended to be an exclusive remedy understood by all to preclude any application of $\S 1$ to state electoral matters.

In these unique circumstances, the binding character of the historical record ${ }^{9}$ may be far different from the bare relevance of history to other issues that sometimes divide the Court. For in none of the other kinds of cases where it was brought to bear did it cast the kind of blinding light that Mr. Justice Harlan sees here. The issues of "state action," "segregation," "incorporation of the bill of

\footnotetext{
8 See 377 U.S. at 602-11; Grilette, The Right to Vote: Politics and the Passage of the Fifteenth Amendment (1965); McGovnex, The Amierican Suffrage MedIEX (1949); Porter, A History of SUtFrage IN the United States (1918); United States Commission on Civil Rights, 1959 Report 19-26; James, The Franing of THE FoURTEENTH AMENDMENT 13 (1956); note 111 infra and accompanying text.

9 But see Wofford, The Blinding Light: The Uses of History in Constitutional Interpretation, 31 U. Cer. L. Rev. 502, 523 (1964): "Do past meanings bind the present? Yet the question has virtually answered itself. If . . the meaning of a word is its use, and if its use can never be found apart from its context, then we need only add that an inseparable constituent of context is the time at which the use occurs to show that a past meaning cannot bind the present. It is precisely the time element of the context of use which is 'the past.' A past use, is looked to a past time, and as such does not bind the present unless the present chooses to be so bound." See also Kurland, "Equal in Origin and Equal in Title to the Legislative and Executive Branches of the Government," 78 HARv. L. Rev. 143, 145-46 (1964): "Neither the question of definition nor that of primacy is resoluble, however much the Court may try, by resort to constitutional history."
} 
rights," corporations as "persons," are not lilke this one, if only because the original understanding was not alleged to be so clear and uniform and because contemporary circumstances, scarcely foreseeable even by the most visionary reconstructionists, are so vastly different.

This article proposes to rake the history of the Fourteenth Amendment still another time to determine whether it proves what Mr. Justice Harlan says it does. ${ }^{10}$ It may appear to be a tedious undertalking, especially because there is already a surfeit of Fourteenth Amendment histories ${ }^{11}$ and because the general character of the period is doubtless thought to be well enough known. Yet, the issues on which those histories focused and the controversies which engendered their selection of materials were different. A matter affecting the integrity of judicial review ought not to be resolved by inference from historical reviews in which this subject was of but incidental concern. ${ }^{12}$ In short, I know of no way fairly to deter-

10 I do this only to determine whether the legislative history on which Mr. Justice Harlan relied supports the original understanding le found in it. Because of the conclusion I reach on this issue, it is unnecessary to determine whether Reynolds v. Sims and the other cases could still have been "rightly" decided even if the original understanding were exactly as Mr. Justice Harlan supposed. See Wofford, supra note 9, and references cited therein.

11 See, e.g., Harris, The Quest for Equaltry (1960); JAMEs, op. cit. supra note 8; 2 Crosskey, Politics and the Constrtution 1083-1118 (1953); tenBroek, The Antistavery Origins of the FourteEnth AMENDMENT (1951); Warsoff, Equaltry

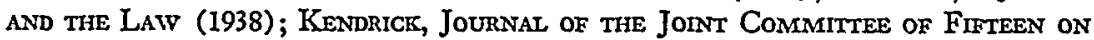
Reconstruction (1914); Flack, The Adoption of the Fourteenth Amendment (1908); 3 Thorpe, Constitutional History of the United States 235-405 (1901); Frantz, Congressional Power To Enforce the Fourteenth Amendment against Private Acts, 73 Yale L.J. 1353 (1964); Black, The Lawfulness of the Segregation Decisions, 69 YALE L.J. 421 (1960); Bickel, The Original Understanding and the Segregation Decision, 69 HARv. L. Rev. 1 (1955); Graham, Our "Declaratory" Fourteenth Amendment, 7 Stan. L. Rev. 3 (1954); Crosskey, Charles Fairman, "Legislative History," and the Constitutional Limitations on State Authority, 22 U. Ckr. L. Rev. 1 (1954); Frank \& Munro, The Original Understanding of "Equal Protection of the Laws," 50 Colum. L. Rev. 131 (1950); Graham, The Early Antislavery Background of the Fourteenth Amendment, 1950 WIs. L. Rev. 479, 610; Fairman, Does the Fourteenth Amendment Incorporate the Bill of Rigbts? The Original Understanding, 2 StaN. L. Rev. 5 (1949); Graham, The "Conspiracy Theory" of the Fourteenth Amendment, 47 YaLE L.J. 371 (1938); Boudin, Truth and Fiction about the Fourteenth Amendment, 16 N.Y.U.L.Q. 19 (1938).

12 See note 11 supra. See also the excellent and comprehensive legislative history of the Fifteenth Amendment in GiLLETrE, op. cit. supra note 8. For an earlier treatment of the same subject, see Mathews, Legislative aNd Judicial History of the FifieENTH AmendMent (1909). 
mine whether the history of the Fourteenth Amendment proves what Mr. Justice Harlan alleges, short of making the same original search that he presumably made before dissenting in Reynolds $v$. Sims.

\section{The "Understanding" of Section Two}

Mr. Justice Harlan's case against the application of $\S 1$ of the Fourteenth Amendment to voting rights consists essentially of two complementary parts. ${ }^{13}$ The first is devoted to evidence that, notwithstanding the very broad language of $\S 1$ which lays down an unqualified normative standard of equal protection and which does not, on its face, admit of any exception, ${ }^{14}$ it was declared and understood at the time of its promulgation not to apply to suffrage qualifications as determined by the states. ${ }^{15}$ The second, and by

\footnotetext{
13 For discussions respecting the current enforceability of $\S 2$, see Margolis, Judicial Enforcement of Section 2 of the Fourteenth Amendment, 23 LaW IN TRaNs. 128 (1963); Zuckerman, A Consideration of the History and Present Status of Section 2 of the Fourteenth Amendment, 30 Ford. L. Rev. 93 (1961); Bonfield, The Right To Vote and Judicial Enforcement of Section Two of the Fourteenth Amendment, 46 CoRNeLl L.Q. 108 (1960). For a brief critical treatment of Mr. Justice Harlan's view of $\S 2$, see Auerbach, The Reapportionment Cases: One Person, One Vote-One Vote, One Value, 1964 Supreme Court Review 1, 74-79.

14 Should this settle the matter? At one time, Mr. Justice Frankfurter implied that "historic limits" need not be controlling in the case of "broad standards of fairness written into the Constitution (e.g., 'due process,' 'equal protection of the laws,' "just compensation')," which, "by their very nature, allow a relatively wide play for individual legal judgment." United States v. Lovett, 328 U.S. 303, 321 (1946) (concurring opinion). May we conclude with Learned Hand that "history does not elucidate [the] contents" of the Fourteenth Amendment, "cast as [it is] in such sweeping terms"? HAND, ThE Bur of Rughts 30 (1958). The Court appeared to agree when, in Burton v. Wilmington Parking Authority, 365 U.S. 715, 722 (1961), it said: 'Because the virtue of the right to equal protection of the laws could lie only in the breadth of its application, its constitutional assurance was reserved in terms whose imprecision was necessary if the right were to be enjoyed in the variety of individual-state relations which the Amendment was designed to embrace." Yet, notice the sudden relevance of history respecting the scope of equal protection in Bell v. Maryland, 378 U.S. 226, 289-316, 335-40 (1964). "Our sworn duty to construe the Constitution requires ... that we read it to effectuate the intent and purposes of the Framers. We must, therefore, consider the listory and circumstances indicating what the Civil $W$ ar Amendments were in fact designed to achieve." Id. at 289 (Goldberg, J., concurring). Compare the attitude expressed by Chief Justice Hughes in Home Bldg. \& Loan Assoc. v. Blaisdell, 290 U.S. 398, 442-43 (1934). For discussions of cases that have expanded the scope of equal protection, see HaRRIs, op. cit. supra note 11, at 59-158; Kurland, supra note 9, at 143-49; Kellett, The Expansion of Equality, 37 So. CAL. L. Rev. 400 (1964).

15377 U.S. at 595.
} 
far the larger, part consists of evidence that however open to doubt the scope of $\S 1$ might otherwise be, the language, juxtaposition, purpose, and legislative history of $\$ 2$ altogether remove that doubt. He thus concludes that $\S 2$ "expressly recognizes the States' power to deny 'or in any way' abridge the right of their inhabitants to vote for 'the members of the [state] Legislature." "16 Section 2 is specifically concerned with voting rights, and it provides an exclusive remedy that precludes or preempts application of $\S 1$. If I understand him correctly, he believes, moreover, that $\$ 2$ equally precludes the application of any earlier provisions of the Constitution to state voting rights. ${ }^{17}$ Because the larger part of his argument is devoted substantially to a treatment of $\S 2$, and because the legislative history of that section has not received much attention elsewhere, it may be well to begin with it.

His first point is that the Court "disregards entirely the significance of $\S 2$, which reads:" 18

"Representatives shall be apportioned among the several States according to their respective numbers, counting the whole number of persons in each State, excluding Indians not taxed. But when the right to vote at any election for the choice of electors for President and Vice President of the United States, Representatives in Congress, the Executive and Judicial officers of a State, or the members of the legislature thereof, is denied to any of the male inhabitants of such State, being twenty-one years of age, and citizens of the United States, or in any way abridged, except for participation in rebellion, or other crime, the basis of representation therein shall be reduced in the proportion which the number of such male citizens shall bear to the whole number of male citizens twenty-one years of age in such State."

From this language he concludes: "If indeed the words of the Fourteenth Amendment speak for themselves, as the majority's disregard of history seems to imply, they speak as clearly as may be against the construction which the majority puts on them."10 For Mr. Justice Harlan, the language of $\S 2$ "expressly recognizes the

\footnotetext{
16 Id. at 594.

17 The inference is drawn from Mr. Justice Harlan's statement that $\$ 2$ expressly recognizes the power of the states to deny or abridge the right to vote (ibid.), plus his note 21 at p. 599, discussed hereafter in the text at notes 28 and 60.

18377 U.S. at 593-94. (Emphasis added by Mr. Justice Harlan.)

19 Id. at 594.
} 
States' power to deny 'or in any way abridge the right of their inhabitants to vote," "subject only to the single remedy provided for in $\S 2$ itself, i.e., a reduction in that state's basis of representation in the House of Representatives (and the Electoral College). ${ }^{20} \mathrm{He}$ necessarily concludes as well in Reynolds $v$. Sims that the phrase in $\$ 2$, "or in any way abridge," includes partial denials to vote resulting from malapportionment that dilutes the political force of some votes. He emphasized that phrase, presumably to make clear how "highly implausible" it would be to contend that $\S 1$ "controls methods of apportionment but leaves the right to vote itself unprotected."21

His second point, by way of reinforcing the first, is to establish that $\$ \S 1$ and 2 were deliberately integrated parts of a single amendment, and that necessarily the special handling of voting rights in $\S 2$ implied, by its simultaneity with, and juxtaposition to, $\S 1$, that voting rights were not protected by $\S 1$. He remarks: ${ }^{22}$

The Amendment is a single text. It was introduced and discussed as such in the Reconstruction Committee, which reported it to the Congress. It was discussed as a unit in Congress and proposed as a unit to the States, which ratified it as a unit.

The comprehensive scope of the second section and its particular reference to the state legislatures preclude the suggestion that the first section was intended to have the result reached by the Court today.

His third point is that throughout the debate on the Fourteenth Amendment, it was frequently asserted that $\S 2$ precluded the application of $\S 1$ to political interests and, in the House at least, "every speaker on the resolution, with a single doubtful exception, assumed without question that ... 'the second section excludes the conclusion that by the first section suffrage is subjected to congressional law." "23 Thus, Mr. Justice Harlan pointed out that "Thaddeus Stevens, [who] introduced debate on the resolution on May $8, \ldots$ in unmistakable terms ... recognized the power of a State to withhold the right to vote: ${ }^{24}$

"If any State shall exclude any of her adult male citizens

from the elective franchise, or abridge that right, she shall
20 Ibid.
21 Id. at 612.
23 Id. at 599.
22 Id. at 594.
$24 \mathrm{Id}$. at 596-98. 
forfeit her right to representation in the same proportion. The effect of this provision will be either to compel the States to grant universal suffrage or so to shear them of their power as to keep them forever in a hopeless minority in the national Government, both legislative and executive." Closing his discussion of the second section, he noted his dislike for the fact that it allowed "the States to discriminate [with respect to the right to vote] among the same class, and receive proportionate credit in representation."

Representative Bingham, "the author of the first section in the Reconstruction Committee and its leading proponent," ${ }^{25}$ was even more emphatic with respect to the preemptive character of $\S 2$. He declared, in words italicized by Mr. Justice Harlan: ${ }^{26}$

"The amendment does not give, as the second section shows, the powver to Congress of regulating suffrage in the several States.

"The second section excludes the conclusion that by the first section suffrage is subjected to congressional law; save, indeed, with this exception, that as the right in the people of each State to a republican government and to choose their Representatives in Congress is of the guarantees of the Constitution, by this amendment a remedy might be given directly for a cause supposed by Madison, where treason might change a State government from a republican to a despotic government, and thereby deny suffrage to the people."

The latter part of Bingham's statement might, of course, imply that Congress derived some authority from $\S 1$ to invalidate state suffrage disqualifications that violated a republican form of government as guaranteed under $\S 4$ of Article IV. In a footnote, lowever, $\mathrm{Mr}$. Justice Harlan denied that this was so: ${ }^{27}$

It is evident from the context of a reference to a republican government that Bingham did not regard limitations on the right to vote or the denial of the vote to specified categories of individuals as violating the guarantee of a republican form of government.

Thus, Bingham is read, in harmony with Mr. Justice Harlan's view of the preemptive effect of $\S 2$, to say that $\S 2$ expressly recognizes exclusive state authority over the franchise, irrespective of all other provisions in the Constitution. Mr. Justice Harlan concludes by

\footnotetext{
$251 d$. at 598.

28 Id. at 598-99.

27 Id. at 599 n. 21.
} 
referring to his Appendix A, containing statements by other speakers who recognized "in express terms or by unmistakable implication, that the States retained the power to regulate suffrage within their borders." 28

Turning to the Senate's consideration of the Fourteenth Amendment, Mr. Justice Harlan notes that debate "began on May 23, and followed the same pattern." ${ }^{29}$ With respect to the effect of $\S 2$, lie quotes Senator Howard's expression of regret that "it did 'not recognize the authority of the United States over the question of suffrage in the several States at all ...'" and that: ${ }^{30}$ " 'The second section leaves the right to regulate the elective franchise still with the States, and does not meddle with that right." "Referring to other "representative statements from the debates" collected in his Appendix B, Mr. Justice Harlan concludes that "it was fully understood by everyone that neither the first nor the second section interfered with the right of the States to regulate the elective franchise."31

To summarize, Mr. Justice Harlan's conclusion that $\S 2$ is preemptive, i.e., that it excludes political interests from the protection that might otherwise be inferred from the general language of other constitutional provisions, is based primarily on the following observations of the treatment and understanding of that section in the thirty-ninth Congress:

1. Section 2 deals specifically and comprehensively with the power of a state to disfranchise citizens, it establishes a special and exclusive means for penalizing the exercise of that power, and its inclusion in the unitary, single text of the Fourteenth Amendment precludes the suggestion that the first section would have any application to issues of state suffrage.

2. The preclusive or preemptive character of $\S 2$ was expressly acknowledged by a number of the principal proponents of the Fourteenth Amendment, "assumed without question" by "every speaker in the House," with a single doubtful exception, and recognized "in express terms or by unmistakable implication" by those speakers, and "fully understood by everyone" in the Senate debates.

It will be seen, however, that there are certain mistakes and seri-

28 lbid. $\quad 29 \mathrm{Id}$. at 600.

$30 \mathrm{Id}$. at 600-01. (Emphasis added by Mr. Justice Harlan.)

31 Id. at 602. 
ous exaggerations in this reading of the congressional history of the Fourteenth Amendment. In the first place, $\delta \S 1$ and 2 of the Amendment were not "introduced and discussed in the Reconstruction Committee" as "a single text." Rather, $\$ 2$ was originally approved by the Joint Commitree and reported to the House on January 22, 1866, as H.R. No. 51, a wholly separate constitutional amendment. It was debated at length and approved by the House in its original form before the proposal that ultimately became $\S 1$ was even reported to the House, on February 13. It was debated at equal length in the Senate in February and March of 1866, nearly two full months before it reappeared in the Joint Committee's Report of April 30 as part of the packaged Fourteenth Amendment. In the course of its consideration, the issue of "preemption by implication" was fully discussed. While the possibility of such an implication disturbed and alienated a number of Radicals otherwise sympathetic to the limited objective of the proposal, the existence of any such implication was emphatically denied by both the House and Senate chairmen of the Joint Committee that reported the bill. Moreover, $\$ 2$ was primarily the handiwork of Thaddeus Stevens, a man of quite different temperament and purpose from Bingham, the principal author of $\S 1$.

In the second place, the unitary amendment introduced in the Joint Committee on April 21, 1866, and drafted by Robert Dale Owen, had little in common with H.R. No. 63 and H.R. No. 51, the separate forerunners of $\$ \S 1$ and 2 , respectively. Owen's proposal was immediately amended almost beyond recognition by the committee, by the substitution of modified versions of H.R. No. 63 and H.R. No. 51 for Owen's first and second sections. Far from being a single text the several parts of which were carefully and deliberately integrated by men of a common mind and a mutual understanding of the implications and interrelationships of the several sections, the Fourteenth Amendment was a package of proposals, the more significant of which were pieced together from independent bills offered by different men at different times and originally debated in Congress as wholly separate amendments. Indeed, the brevity of the three-day House debate on H.R. No. 127, the packaged Fourteenth Amendment bill, is probably attributable to the fact that its noost significant components had previously been considered at length. A more accurate description of the placement of $\S 2$ in the Fourteenth Amendment is that "[i]t became a part of 
the Fourteenth Amendment largely through the accident of political exigency rather than through the relation which it bore to the other sections of the Amendment." 32

The Appendix ${ }^{33}$ roughly describes the sequence of proposals culminating in the package amendment and a breakdown of events after H.R. No. 127, the package amendment, was reported to Congress.

In the third place, even confining ourselves to the brief debate of the packaged Fourteenth Amendment in the House between May 8 and 10, 1866, it was not true that "every Speaker on the resolution, with a single doubtful exception, assumed without question that ... 'the second section' " preempted the first with regard to suffrage. To the contrary, several speakers insisted that $\$ 1$ might apply to suffrage, and the "exception" acknowledged by Mr. Justice Harlan was by no means "doubtful," either in terms of what he said or in terms of his position as a member of the Joint Committee. Moreover, during the long, previous debate on $\S 2$ in the House and Senate, its principal proponents emphasized that it did not acknowledge the constitutionality of state disfranchisement laws.

In the fourth place, $\S 2$ was designed primarily to meet a particular, separable, and immediate problem of protecting the Republican hegemony in Congress, quite aside from any long-term effort to secure the right to vote against arbitrary discrimination by the states. Viewing it as a device to induce the southern states to enfranchise the Negro, the principal proponents had every reason to suppose only that it would fail. Viewing it as a device to prevent southern representatives from becoming a substantial force in Congress, however, they had considerable reason to suppose that it would succeed.

In the fifth place, the phrase in $\S 2$, "or in any way abridged," did not refer to voting discrimination resulting from malapportionment but to something having nothing to do with malapportionment. Indeed, the subject of malapportionment was never even considered by the thirty-ninth Congress, and the penalty to be applied against states that demied the right to vote was probably incapable of application to discrimination by way of malapportion-

32 Mathews, op. cit. supra note 12, at 14.

33 P. 86, infra. 
ment. Section 2 was neither "comprehensive in scope" nor at all suitable to any resolution of the undiscussed issue of malapportionment.

In short, notwithstanding the express statements by Bingham and Howard and the more equivocal statements of others on whom Mr. Justice Harlan depended in his opinion, there was probably no reliable understanding whatever that $\S 2$ would preclude Congress (or the courts) from employing sources of constitutional authority other than $\S 2$ to affect state suffrage power. The history demonstrating that there was no such consensus follows.

On December 4, 1865, the first day of the first session of the Thirty-ninth Congress, Thaddeus Stevens won House approval for his resolution to establish a Joint Committee on Reconstruction to inquire into the condition of the states lately in rebellion and to report all appropriate bills. ${ }^{34}$ With slight modification, the resolution was approved by the Senate on December $12 . .^{35}$ The committee, of fifteen members, consisted of twelve Republicans and three Democrats. The Democrats were Rogers (New Jersey) and Grider (Kentucky) of the House, and Reverdy Johnson (Maryland) of the Senate. The Republicans were Stevens (Pennsylvania), chairman of the House section of nine members including Bingham (Ohio), Washburne (Illinois), Morrill (Vermont), Conkling (New York), Boutwell (Massachusetts), and Blow (Missouri); and Fessenden (Maine), chairnian of the Senate section of six members including Howard (Michigan), Williams (Oregon), Grimes (Iowa), and Harris (New York). ${ }^{36}$

On December 18 Stevens rose in the House to speak at length in criticism of President Andrew Johnson's message to Congress, in which Johnson had urged the speedy restoration of the southern states and the readmission of southern representatives to Congress. ${ }^{37}$ In the course of his remarks, Stevens spolke favorably of a proposal he had put forward on December 5, to base representation in Con-

\footnotetext{
34 Cong. Globe, 39th Cong., 1st Sess. 6 (1866) (hereafter cited as GroBE).
}

35 Id. at 30.

36 Id. at 46-47, 57. See also The Journal of the Joint Committee of Fifteen on Reconstruction, in KeNDRICK, op. cit. supra note 11, at 37-39 (hereafter cited as KENDRICK). For profiles of the members of the Joint Committee, see KENDRICK at 155-97; JAMES, op. cit. supra note 8, at 41-46.

37 GLOBE at 72-75. 
gress upon the number of electors (voters) rather than upon the population in each state. ${ }^{38} \mathrm{He}$ announced the objectives of that proposal to be: ${ }^{39}$

a) to secure perpetual ascendency to the party of the Union.

b) to render our republican Government firm and stable forever.

c) to avoid a Democratic majority in Congress and in the Electoral College.

d) to avoid assumption of the rebel debt and repudiation of the Federal debt.

e) to avoid the oppression of the freedman; the reamendment of the state constitutions, and the reestablishment of slavery.

Stevens made very plain just what it was that made him so apprehensive of a Democratic takeover unless some change were made in the formula for representation in Congress as established by Article I, $\$ 2$, cl. 3. Under the then existing formula, representatives were apportioned according to population with the exception that every five slaves were counted only as three people. As a result of the Emancipation Proclamation and the Thirteenth Amendment, the Confederate states would be entitled to a gain in congressional representation reflecting an increase in representational basis of two-fifths of four million Negroes recently made free. According to Stevens' figures, the unreconstructed South would be entitled to eighty-two representatives in Congress, of whom thirty-seven would "represent" disfranchised Negroes, unless the apportionment formula of Article I, $\S 2$, were changed. The net political effect of the Civil War might otherwise be to increase southern representation in Congress and the Electoral College by thirteen completely hostile Democratic votes. To avoid that effect, he endorsed the proposal to amend the Constitution "to base the representation in Congress upon the number of electors, instead of the population, of the several states." 40

Even under the proposed change, of course, the South could still increase its representation to the extent that Negroes were allowed to vote. But that possibility, far from worrying Stevens, served his interests equally well. For one thing, he greatly favored Negro suffrage and consistently supported all efforts toward that end, to the extent he thought them politically feasible. For another, he held 
that the Negro vote would moderate the influence of any increase in southern representation: ${ }^{41}$

If they should grant the right of suffrage to persons of color, I think there would always be Union white men enough in the South, aided by the blacks, to divide representation and thus continue the Republican ascendency. If they should refuse to thus alter their election laws it would reduce the representatives of the late slave States to about forty-five and render them powerless for evil.

On January 9, Stevens proposed in the Joint Committee a new amendment to apportion representatives according to the number of voters in each state who were natural-born or naturalized citizens of the United States and at least twenty-one years of age. ${ }^{42}$ The proposal was not satisfactory to the rest of the committee, however, probably because they had been surprised to learn what effect apportionment strictly according to voters would have among the northern states, as suggested on January 8 in Representative Blaine's remarks before the House. Blaine had acknowledged the declared and limited objective of Stevens' plan. ${ }^{43}$ But he also noted that limitation on southern representation would not be the only effect, if representatives were to be apportioned according to the number of voters in each state. Suffrage standards varied considerably among the northern states, as did the respective numbers of qualified voters, even between states with reasonably similar suffrage standards. Blaine pointed out, for instance, that because pioneer California had a far higher percentage of males over the age of twenty-one than did Vermont, 58 per cent of the Califormia population consisted of voters as against only 19 per cent in Vermont, even though the two states had similar total populations and similar voter qualifications. The effect of the Stevens plan would operate greatly to favor California over Vermont, and to accomphsh similar representational dislocations elsewhere outside the South. ${ }^{44}$

41 Ibid.

42 KENDRICK at 41 . The proposal was the same as that which Stevens had made to the House on December 5, before the Joint Committee was established. His original proposal had been referred to the Judiciary Committee. Grobe at 10.

43 Blaine had duly noted that: "The effect contemplated and intended by this change ... is to deprive the lately rebellious States of the unfair advantage of a large representation in this House, based on their colored population." GLOBE at 141. 44 lbid. 
To avoid this sort of unwanted incidental effect, the Joint Committee referred Stevens' proposal to a subcommittee for modification..$^{45}$ On January 20, the subcommittee, consisting of Stevens, Fessenden, Howard, Conkling, and Bingham, reported the following proposals, in the alternative, to the full committee: ${ }^{46}$

Representatives and direct taxes shall be apportioned among the several States within this Union, according to the respective numbers of citizens of the United States in each state; and all provisions in the Constitution or laws of any State, whereby any distinction is made in political or civil rights or privileges on account of race, creed or color, shall be inoperative and void.

Representatives and direct taxes shall be apportioned among the several States which may be included within this Union, according to their respective numbers, counting the whole number of citizens of the United States in each state; provided that, whenever the elective franchise shall be denied or abridged in any State on account of race, creed or color, all persons of such race, creed, or color, shall be excluded from the basis of representation.

The second of these alternative proposals was approved by the committee, with the modification that "creed" was deleted, and "persons in each State, excluding Indians not taxed" was substituted for "citizens of the United States in each State." Stevens reported this proposal to the House in behalf of the committee, and it was designated H.R. No. $51 .^{48}$

We may appropriately pause at this point to inject several observations generally in agreement with $\mathrm{Mr}$. Justice Harlan's view of what was implied by $\$ 2$. First, the fact that the Joint Committee considered an amendment to prohibit voting discrimination on racial

\footnotetext{
45 KeNDRICK at $45-47$.
}

46 Id. at 50-51. At the same time, the subcommittee reported the following proposed amendment as a companion to whichever of the alternatives was approved. "Congress shall have power to make all laws necessary and proper to secure to all citizens of the United States, in every State, the same political rights and privileges; and to all persons in every State equal protection in the enjoyment of life, liberty and property." On Stevens' motion, it was separated and, on January 24, this proposal was referred to a subcommittee consisting of Bingham, Boutwell, and Rogers. Id. at 56.

47 Id. at 51-54. As approved by the committee, the proposal is nearly the same as that suggested on January 8 by Blaine. See Globe at 141-42.

48 GLOBE at 351. 
grounds does seem to imply that it otherwise regarded state laws providing for such discrimination as constitutional. ${ }^{49}$ Second, the fact that a more limited reduction-of-representation-basis alternative was simultaneously considered and adopted, and that the proposal to prohibit discrimination on the basis of race was not adopted, appears to imply that $\S 2$ itself recognizes the exclusive power of states over suffrage qualifications. Beyond this, the speeches by Stevens ${ }^{50}$ and Conkling ${ }^{51}$ in support of H.R. 51 initially appear to be to the same effect.

Nevertheless, subsequent developments in the House quickly dispelled the impression that might otherwise have persisted, the impression that the amendment proposed by H.R. No. 51 would preclude the application of any other constitutional provision to state suffrage qualifications. The clarification of the nonpreemptive effect of H.R. No. 51 developed in response to complaints by a number of Radicals that the bill might rob Congress of power to broaden the franchise, which, they insisted, it already had.

On January 10, Kelley of Pennsylvania argued at length that Article I, $\S 4$, authorizing Congress to "alter" the "manner" of holding elections, permitted Congress to abolish state suffrage dis-

\footnotetext{
40 But note that the committee was still considering the proposal reproduced supra, at note 46 , as an additional amendment.

50 GLOBE at 351: "It proposes to change the present basis of representation to a representation upon all persons, .... It does not deny to the States the right to regulate the elective franchise as they please. ..."

iI Id. at 357: "To level this favoritism which has come out of the results of the war [i.e., the imminent prospect that rebel state congressional power would be enhanced by adding representatives attributable to free, but disfranchised, $\mathrm{Ne}$ groes], three modes have been proposed, each of course by way of amendment to the Constitution.

"First. To make the basis of representation in Congress and in the Electoral College consist of sufficiently qualified voters alone.

"Second. To deprive the States of the power to disqualify or discriminate politically on account of race or color.

"Third. To leave every State perfectly free to decide for itself, not only who shall vote, but who shall belong to its political commumity in any way, and thus to say who shall enter into its basis of representation and who shall be shut out. What the States decide for themselves in their own affairs they decide for themselves in their national affairs. If any State contains a class unfit or supposed to be unfit for political rights, or unworthy to act politically in the States, this class shall not be put upon the nation as fit and worthy to be represented in the nation's councils.

"The last proposition has met the approval of the committec, and the others have not."
} 
qualifications that it found to be incompatible with republican forms of government. ${ }^{52}$ To guard against the possibility of H.R. No. 51 being misunderstood as preempting that authority, he offered the following amendment on January $23:^{53}$

Provided, That this article shall not be construed to affect the power of Congress to regulate the qualifications for electors of the most numerous branch of the Legislatures of the several States.

On the same day, Farnsworth of Illinois argued that congressional power to broaden the franchise already existed under Article IV, $\S 4$, and that this section "ought to be taken into consideration by this Congress and enforced." ${ }^{4} \mathrm{He}$ then turned to what he thought might be the dangerous and debilitating implication of H.R. No. 51.55

Sir, I will not admit that any State has the right to disfranchise a portion of its citizens; and if this proposition makes, expressly or by implication, any such admission, I cannot vote for it. ... [B]y no vote of mine shall there be incorporated in the Constitution a provision which shall, even by implication, declare that a State may disfranchise any portion of its citizens on account of race or color.

On January 24, Eliot of Massachusetts agreed that Congress could invalidate state suffrage disqualifications under its authority to guarantee a republican form of government in each state. Like Farnsworth he expressed objections to the implications of Stevens' proposed amendment. ${ }^{56}$

On January 25, Higby of California argued that no "State which excludes any class of citizens [from voting] on account of race or color is republican in form," 57 and that he was tentatively opposed to H.R. No. 51 because he thought "it gives a power to the States to make governments that are not republican in form." 58 Stevens' response at this time was confusing: $:^{59}$

MR. STEvens. I say to my friend if I thought that according to any portion, or verse or chapter of Lindley Murray, by any fair construction of language, such an interpretation could

\footnotetext{
52 Id. at 182-83, 408-09, 412.

53 Id. at 377.

54 Id. at 383.

55 lbid.
}

56 Id. at 406.

57 Id. at 427.

$58 \mathrm{Id}$. at 428.

59 lbid. 
be given as he gives, I would vote against it myself. But I do not believe there is anything in that objection.

MR. HYGBY. "Provided, that whenever the elective franchise shall be denied or abridged in any State on account of race or color, all persons of such race or color shall be excluded from the basis of representation."

Mr. Stevens. May I ask my friend one question? Does that take from or add to any powers which the States now have?

$M_{R}$. Hraby. I beg pardon of the gentleman; he cannot get rid of this proposition in that way. I ask him distinctly if it does not acknowledge a power in a State to do such a thing.

Mr. Stevens. Yes, sir, it does acknowledge it, and it has always existed under the Constitution.

Mr. Hrgby. I do not acknowledge that it is in the Constitution as it now is.

Mr. Stevens. Then we do not give it to them.

Then, on January 25, Bingham laid out his own views respecting the nonpreemptive effect of H.R. No. 51 and the broad power of Congress to regulate suffrage in the states. The quotation is rather long, but it is unusually rewarding, especially to determine the correctness of Mr. Justice Harlan's understanding" "that Bingham did not regard limitations on the right to vote or the denial of the vote to specified categories of individuals as violating the guarantee of a republican form of government": ${ }^{01}$

\footnotetext{
60377 U.S. at 599 n. 21.

61 GroBe at 431-32. In addition to Kelley, Farnswortl, Eliot, Higby, and Bingham, the following members of the House also declared their belief at the time that Congress already possessed authority over state suffrage qualifications: Shellabarger, Ohio (Art. IV, $\$ 4$ forbids a state from "excluding an entire race from the right of the elective franchise"), $i d$. at 405; Cook, Illinois (Art. IV, $\$ 4$ might apply if a state denied a majority of its inhabitants the riglit to vote, by class suffrage restrictions), $i d$. at 411; Boutwell, Massachusetts (relying on a principle of government recognized in the Declaration of Independence and derived from natural law), id. at 309; Julian, Indiana (relying on Art. IV, \$4, and the Thirteenth Amendment), $i d$. , 39th Cong., 1st Sess. App. 56 (1866). A number of these arguments continue to find favor with contemporary scholars. See, e.g., 1 Crosskey, op. cit. supra note 11, at 522-41; Bonfield, Baker v. Carr; New Light on the Guarantee of Republican Government, 50 CALIF. L. Rev. 245 (1962); Bonfield, The Guarantee Clause of Article IV, Section 4: $A$ Study in Constitutional Desuetude, 46 MrNw. L. REv. 513 (1962); Maggs \& Wallace, Congress and Literacy Tests: $A$ Comment on Constitutional Power and Legislative Abnegation, 27 LAw \& CoNTEMP. Pros. 510 (1962); Werdegar, The Constitutionality of Federal Legislation To Abolish Literacy Tests: Civil Rights Commission's 1961 Report on Voting, 30 Geo. Wash. L. Rev. 723 (1962).
} 
The guarantee of your Constitution, that the people shall elect their Representatives in the several States, cannot be set aside or impaired by inserting in your Constitution, as a penalty for disregarding it the provision that the majority of a State that denies the equal rights of the minority shall suffer a loss of political power.

I have endeavored to show that the words of the Constitution, the people of "the States shall choose their Representatives," a majority of the free male citizens of the United States in every State of this Union, being of full age, shall have the political power subject to the equal right of suffrage in the minority of free male citizens of full age. There is a further guarantee in the Constitution, of a republican form of government to every State, which I take to mean that the majority of the free male citizens in every State shall have the political power. I submit to my friend that this proviso is nothing but a penalty for a violation on the part of the people of any State of the political right of franchise guaranteed by the Constitution to their free male fellow-citizens of full age. ...

Mr. HigBY. I ask whether under the amendment we propose to adopt as a part of the Constitution of the United States, a State could not, by virtue of the proviso which it contains, have a right to disfranchise any class of citizens on account of race or color?

Mr. Bingham. . . . I say that the proviso is a penalty, and nothing but a penalty, inflicted on the State if its ruling class disregard and violate the guarantees of the Constitution of the political right of all the free people therein, being male citizens of the United States of full age, to participate in the choice of electors, by imposing on any part of one class special disabilities not imposed on the other class.

The guarantee in the first article of the second section of the Constitution rightly interpreted is, as I claim, this, that the majority of the male citizens of the United States of full age in each State shall forever exercise the political powver of the State with this limitation, that they shall never by caste legislation impose disabilities upon one class of free male citizens to the denial or abridgment of equal rights. The further provision is that the United States shall guarantee to each State a republican form of government, which means the majority of male citizens of full age in each State shall govern, not however, in violation of the Constitution of the United States or of the riglits of the minority. . . .

Mr. BROMWELL. I ask the gentleman whether the pending amendment reported from the committee does not, by forcible implication, if sanctioned by three fourths of the State Legis- 
latures, admit that a majority may disfranchise a minority?

Mr. Bingham. As I have before stated, and I beg the gentleman's pardon for asking his attention to the fact there has not been such a construction, in my opinion, of a law which imposes only a penalty, for centuries, if ever, in any country where the common law obtains. The construction insisted upon by the gentleman amounts to this, that a law which inflicts a penalty or works a forfeiture for doing an act, by implication authorizes the act to be done for doing which the penalty is inflicted. There cannot be such a construction of the proviso. It is a penalty. It says in terms that if any of the States of the United States shall disobey the Constitution, that as a penalty such State shall lose political power in this House, to the extent of the whole class or race against any part of whom the unjust discrimination has been made. ...

You place upon your statute-book a law punishing the crime of murder with death. You do not thereby, by implication, say that anybody may, of right, commit murder. You but pass a penal law. You do not prohibit murder in the Constitution; you guarantee life in the Constitution. You do not prohibit the abuse of power by the majority in the Constitution in express terms, but you guarantee the equal right of all free male citizens of full age to elect Representatives; and by the proviso you inflict a penalty upon a State which denies or abridges that right on account of race or color. In doing that we are not to be told that we confer a power to override the express guarantees of the Constitution. We propose the penalty in aid of the guarantee, not in avoidance of it.

As though Bingham's emphatic remarks had not sufficed, Stevens directly met the concern of his Republican colleagues on January 31 , after reporting the following modification of H.R. No. 51 in behalf of the Joint Committee: ${ }^{62}$

Representatives shall be apportioned among the several States which may be included within this Union according to their respective numbers, counting the whole number of persons in each State, excluding Indians not taxed: Provided, That whenever the elective franchise shall be denied or abridged in any State on account of race or color, all persons therein of such race or color shall be excluded from the basis of representation.

Defending his bill against the alarms of his own Radical colleagues, Stevens declared: ${ }^{63}$

62 GLOBE at 535.

63 Id. at 536 
But some of our friends are appprehensive that this is an implied permission to the States to regulate the elective franchise within the States. Now, Sir, I venture to say that there is no good philologist who, upon reading this proposed amendment, will for a single moment pretend that it either grants a privilege or takes away a privilege from any State on that subject. It does, however, punish the abuse of that privilege if it exists.

During the concluding debate on H.R. No. 51, no member of the House disputed Stevens' interpretation of what was, after all, primarily his own bill. ${ }^{64}$ When, on the same day, the bill was approved by a vote of 120 to 46, Stevens, Bingham, Lawrence, Kelley, and Farnsworth were among the "yeas."65 The first two had declared that H.R. No. 51 would not preempt congressional power over 'suffrage qualifications. The latter three had declared, before Stevens reassured them, that they might vote against the bill were it understood to have a preemptive effect. Of those expressing some anxiety lest H.R. No. 51 be taken to imply exclusive state power over suffrage qualifications, only Eliot voted against the bill, and Higby abstained.

It is true, of course, that Stevens' reassurance of January 31-that H.R. No. 51 did not attempt to resolve the separate issue of the extent to which Congress might regulate state suffrage requirementswas not then made in reference to $\$ 1$ of the Fourteenth Amendment. The explanation is simply that $\$ 1$ was not formally reported to the House until February 13, two weeks after H.R. No. 51 had been approved. ${ }^{66}$ It is also true that when the package amendment

64 It was modified in line with Blaine's proposal of January 8. See note 47 supra. 65 GLOBE at 538.

6e Id. at 813. The bill, H.R. No. 63, provided: "The Congress shall have power to make all laws which shall be necessary and proper to secure to the citizens of each State all privileges and immunities of citizens in the several States: and to all persons in the several States equal protection in the rights of life, liberty, and property."

This proposal represented the Joint Committee's modification of the subcommittee's recommendation of January 20 , quoted in note 45 supra. The following intermediate version was reported by the subcommittee and rejected by a 5 to 5 vote of the committee, on January 27: "Congress shall have power to make all laws which shall be necessary and proper to secure all persons in every state full protection in the enjoyment of life, liberty and property; and to all citizens of the United States in any State the same immunities and also equal political rights and privileges." Fessenden, Williams, Morrill, and Bingham voted for it. KendRICK at 
was under consideration in the House on May 8, Stevens did express his disappointment with $\S 2$. His disappointment was announced, however, not on the basis that $\$ 2$ preempted any authority Congress might previously have enjoyed over suffrage under existing constitutional provisions, or on the basis that it preempted any authority Congress might prospectively acquire under $\S 1$. He was disappointed, rather, because he preferred the reduction-of-representation penalty established by H.R. No. 51 to the less stringent penalty provided by $\S 2$ as finally adopted. ${ }^{67}$ Under H.R. No. 51 , the basis of a state's representation would be reduced according to the whole number of Negroes in a state if any Negro were disfranchised because of race or color. Under the revision accomplished by $\S 2$, as reported on April 30, a state's basis of representation would be reduced only in proportion to the actual number of disfranchised adult male citizens..$^{88}$

Finally, there are the remaining passages from Stevens' statement of May 8 on which Mr. Justice Harlan relied: ${ }^{69}$

This amendment ... allows Congress to correct the unjust legislation of the States, so far that the law which operates upon one man shall operate equally upon all. Whatever law punishes a white man for a crime shall punish the black man precisely in the same way and to the same degree. Whatever

56-57. On February 3, Bingham moved to substitute the proposal which became H.R. No. 63, and, on February 10, the committee agreed that it be reported to Congress. Id. at 60-62.

67 GLOBE at 2459-60.

68 Compare H.R. No. 51, text supra note 62, with $\$ 2$ of H.R. No. 127 as reported to the House on April 30, 1866, id. at 2286: "Representatives shall be apportioned among the several States which may be included within this Union according to their respective numbers, counting the whole number of persons in each State, excluding Indians not taxed. But whenever in any State the elective franchise shall be denied to any portion of its male citizens not less than twentyone years of age, or in any way abridged, except for participation in rebellion or other crine, the basis of representation in such State shall be reduced in the proportion which the number of male citizens shall bear to the whole number of such male citizens not less than twenty-one years of age."

The change in the reduction-of-representation formula in $\$ 2$ of H.R. No. 127, from the formula proposed in H.R. No. 51, reflects criticism that a reduction based only on disfranchisement solely because of race was readily subject to evasion, that it was unfair to other disfranchised groups, and that representation should be reduced only according to the actual number disfranchised. See id. at $353,385,407,433,765$.

69 Id. at 2459. 
law protects the white man shall afford "equal" protection to the black man. Whatever means of redress is afforded to one shall be afforded to all. Whatever law allows the white man to testify in court shall allow the man of color to do the same. These are great advantages over their present codes. Now different degrees of punishment are inflicted, not on account of the magnitude of the crime, but according to the color of the skin. Now color disqualifies a man from testifying in courts, or being tried in the same way as white men. I need not enumerate these partial and oppressive laws. Unless the Constitution should restrain them those States will all, I fear, keep up this discrimination, and crush to death the hated freedmen.

There surely is nothing in this statement to exclude the application of the Equal Protection Clause to the "partial and oppressive laws" that utterly failed to "afford 'equal' protection to the black man," by disfranchising him solely because of his race or color. The whole character of the discussion suggests the opposite. Surely the right to vote is one essential protection that white men enjoyed, and surely equal protection would require that black men enjoy it to the same extent. And surely, too, one way of reshaclling the hated freedman was to bar him from having any voice in government. If the special function of the Equal Protection Clause was to restrain the states from crushing the freedman, why would it not apply to guarantee him an equal right to vote?

But Stevens' ensuing remarks on $\S 2$ are nevertheless taken by $M r$. Justice Harlan to preclude the unqualified force of what Stevens had just said: ${ }^{70}$

If any State shall exclude any of her adult citizens from the elective franchise, or abridge that right, she shall forfeit her right to representation in the same proportion. The effect of this provision will be either to compel the States to grant universal suffrage or so to shear them of their power as to keep them forever in a hopeless minority in the national Government, both legislative and executive.

Does this evidence an understanding on Stevens' part that an exception was to be read into the unqualified language of $\S 1$ and that the Equal Protection Clause could not be applied against partial and oppressive laws denying the freedmen their voice in government? Possibly, but certainly not necessarily. The better inference, if any

70 Ibid. 
at all is to be drawn, is that he was now addressing himself to a special provision designed to protect the Republican hegemony in Congress. It is to be remembered that the very first issue to which Stevens addressed himself in the Thirty-ninth Congress was the avoidance of a Democratic takeover that would come about through the readmission of an increased number of southern representatives elected only by white secessionists, in coalition with the northern Democrats already in Congress. ${ }^{71}$ This was the immediate problem posed by the apportionment formula in Article I, and this was the problem that the special penalty of H.R. No. 51 as carried into $\$ 2$ of H.R. No. 127 was designed to solve. ${ }^{72}$ It was a problem that might require special handling, moreover, even if the election of representatives by whites only were clearly in violation of the Equal Protection Clause or of other constitutional provisions.

It is also to be remembered that Stevens, as well as most of the other Radicals, did not place much faith in the self-executing capacity of constitutional provisions, unaided by supplementary legislation. So far as they were concerned, the Thirteenth Amendment, of

71 See text supra, at note 40 ; GLoBe at $141,351,357,385,410,2459,2467,2468$, $2510,2539,2767,2963$.

72 The announced secondary objective, to induce the states to extend the franchise in order to maintain full representation in Congress, could scarcely have been taken seriously by any member of the Joint Committee. During practically the whole time that H.R. No. 51 was under consideration, the Joint Committee was holding hearings on conditions in the South. The question was repeatedly raised whether the states were hikely to extend the franchise in response to the inducement of H.R. No. 51. Almost none of the witnesses interrogated on this point, from Union commanders to white, native southerners, felt that the states would extend the franchise rather than suffer a loss in representation. See Report of the Joint Committee on Reconstruction, H.R. ReP. No. 30, 39th Cong., 1st Sess. (1866) at pp. 5, 137, 158, 162 (Part II), pp. 99, 132 (Part III), pp. 42, 132 (Part (IV). Here is a colloquy of February 10, 1866, between Senator Howard and B. R. Grattan, a native Virgimian and member of the Virginia House of Delegates:

"Question. Are you aware of the nature of the constitutional amendment now pending in the Senate of the United States in reference to the basis of representation [H.R. No. 51]?

"Answer. Yes, sir.

"Question. You know its effect?

"Anstver. Yes.

"Question. [Howard explains that the proposed amendment would operate to reduce a state's basis of representation by all of a given race or color if any of that race or color were denied the right to vote.] I want to ascertain your opinion of that subject, whether you think the people of Virgimia are likely ever to consent to let negroes vote?

"Answer. I should say not, sir, under no circumstances." 
its own force, had accomplished little. This same Congress had already found it necessary to follow the Thirteenth Amendment with the Civil Rights Act, even after the First Freedmen's Bureau Act, and to continue the presence of an occupation force in the South to protect the Negro. In this very speech, Stevens had spoken of $\S 1$ as significant because it "allows Congress to correct the unjust legislation of the states," not because it would by itself magically put an end to unjust treatment of the Negro. ${ }^{73}$ Section 1 might make it possible for Congress subsequently to complete the reconstruction of the South, but it did not by itself effect that reconstruction.

In the meantime, there was the immediate problem of preserving Republican control of Congress, for its own sake as well as to carry through with appropriate legislation that might ultimately accomplish the aims of $\S 1$. Section 2 would provide a means for preserving that control and for quieting complaints that the present exclusion of southern representatives was not constitutional. If the southern states refused to enfranchise the Negro without waiting for the enforcement of supplementary legislation or court orders (which might never come), ${ }^{74}$ they could at least be stripped of thirty-seven representatives and, as Stevens said, reduced to "a hopeless minority in the national Government."

This view of $\S 2$ as discussed by Stevens makes fully as much sense of his remarks as the preemptive view proffered by $\mathrm{Mr}$. Justice Harlan. It is, moreover, in keeping with Stevens' general character as a confirmed Radical who regarded the Confederate states as conquered provinces, not to be trusted or indulged. ${ }^{75}$ It is more consistent with the importance he expressly attached to the maintenance of Radical control of the Congress. To borrow a metaphor that both

73 Note that several members of the House had expressed the view that systematic disfranchisement was already subject to congressional correction which they regretted had not been forthcoming. See also the views of Stevens and Boutwell, text infra, at notes 101 and 102. Throughout the consideration of the Fourteenth Amendment, no particular reliance was placed on the prospect that the courts would apply its provisions in a self-executing fashion, unaided by supplementary legislation and executive enforcement. The Radical distrust of the courts is traceable in part to their disappointment with Dred Scott v. Sanford, 19 How. 393 (1857).

74 See notes 72 and 73 supra.

75 See, e.g., Globe at 72-75; Kendrick at 155-69; Woodburn, Life of Thaddeus Stevens (1913); Woodlex, Thaddeus Stevens (1934); Current, Old Thad Stevens (1942). 
Bingham and Fessenden had employed on the same issue, it suggests that $\S 2$ no more recognizes a right of the states to disfranchise Negroes under $\S 1$, than a separate statute forfeiting the right to vote of a criminal convicted of larceny recognizes his right to commit larceny.

On January 31, H.R. No. 51 went to the Senate. ${ }^{76}$ The issue of preemption was again raised, and the record of debate again discloses a lack of common understanding among the senators. Senator Sumner maintained that Congress had the power and duty immediately to enfranchise the Negro under Article I, $\S 2$, Article IV, $\S 4$, the Thirteenth Amendment, the war power, the power over federal territories, and an inherent power derived from the sense of the Declaration of Independence, the Preamble, and the Constitution combined. ${ }^{77}$ In his remarks of March 7, he expressed his view that H.R. No. 51 would appear to constitutionalize state disfranchisement of Negroes. ${ }^{78}$ Fessenden, the Senate chairman of the Joint Committee (of which Sumner was not a member), disagreed on both counts. He held that currently the states had exclusive authority over suffrage qualifications, ${ }^{79}$ but he emphatically denied that H.R. No. 51 preempted any authority that Congress itself might have of that kind: ${ }^{80}$

Opinions differ ... but for the sake of the argument, admit that Congress has the power, how in the world does this proposition deprive them of any power they have. What is the expression? . . . Suppose Congress has the power to decide that the colored people shall vote, does this give it away? Does this diminish it? If it exists in the Constitution today, is Congress deprived of the power on account of this prohibition? Is it affected in the slightest possible degree in any way? Every man must see that it is not.

Senator Yates of Illinois argued that Congress could extend the franchise under the Thirteenth Amendment, and he expressed concern that H.R. No. 51 might deprive them of that power. ${ }^{81}$ Wilson of Massachusetts disagreed on the power of Congress, but he was as emphatic as Fessenden that H.R. No. 51 did not affect that question in any way. ${ }^{82}$ On March 9, Yates reiterated his position that Con-

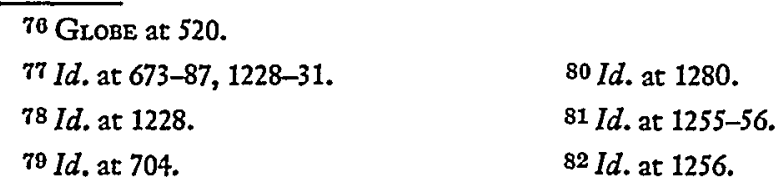


gress could and should act to enfranchise the Negro under Article I, $\$ 2$ (election "by the people") and the Thirteenth Amendment. Again he protested against H.R. No. 51 to the extent that it seemed to him to recognize the right of the states to disfranchise these people. ${ }^{83}$ Again Fessenden denied any such implication, emphasizing that H.R. No. 51 merely provided a special penalty and did not acknowledge any right of the states to do the thing for which they would be penalized. ${ }^{84}$ Still the question persisted, with Senator Stewart of Nevada asserting that while he disagreed with Sumner's view of congressional power, he agreed with Sumner's impression of H.R. No. 51:" "I do not think he is right; but I think if he is right, it [H.R. No. 51] takes away the right."

Finally, on March 9, the same day that much of this discussion occurred, H.R. No. 51 was put to a vote. It lost by 25 to 22 , falling short of the necessary two-thirds support for a constitutional amendment. ${ }^{86}$ Fessenden and Wilson voted for it, and were to vote for it again when modified H.R. No. 51 reappeared as $\S 2$ of the packaged Fourteenth Amendment in May. Stewart, Sumner, and Yates voted against it, but were subsequently to vote in favor of the packaged Fourteenth Amendment. Senator Wade, another who believed that Congress might already possess authority to enfranchise Negroes, voted for it. ${ }^{87}$

Immediately after H.R. No. 51 failed to secure the necessary twothirds vote in the Senate, Sherman of Ohio reopened the issue. On March 12 Sumner moved to amend H.R. No. 51 by substituting the following penalty provision: ${ }^{88}$

Provided: That whenever male citizens of the United States over the age of twenty-one years shall be excluded from the elective franchise in any State, except for participation in rebellion, the basis of representation therein shall be reduced in proportion which the number thus excluded bears to the whole number of male citizens of the United States over the age of twenty-one years in such State.

In view of the similarity between Sumner's proposal and $\S 2$ of the Fourteenth Amendment as finally adopted, and its contrast with H.R. No. 51, which provided for a reduction-of-representation

\footnotetext{
83 Id. at $1278-79$.

86 Id. at 1289.

$84 \mathrm{ld}$. at 1279.

87 Id. App. at 122.

$85 \mathrm{Id}$. at 1280 .

88 Id. at 1289.
} 
basis only for exclusions based on race or color, it may be of interest to learn why Sumner modified H.R. No. 51 as he did: ${ }^{89}$

With the indulgence of the Senate, I will merely call attention to the fact that that proposition is not open, I think, as will appear on its face, to any evasions; in the second place, it contains no words which can imply any recognition of inequality of rights; and in the third place, it contains no words which can imply any recognition of the right of a State to disfranchise on account of color or race; and therefore it seems to meet the objections which were adduced against the pending proposition.

Sumner's remarks were almost the last references to H.R. No. 51 in Congress, until the bill reappeared in only slightly altered dress as $\S 2$ of H.R. No. 127, the packaged Fourteenth Amendment worked out by the Joint Committee between April 21 and 28. ${ }^{90}$ On April 30, Stevens and Fessenden reported H.R. No. 127 to both Houses. ${ }^{91}$ The first two sections provided: ${ }^{22}$

89 Id. at 1321.

${ }^{80}$ See Kentrick 82-120. The proposal for a package amendment was put forward in the committee by Stevens, on the suggestion of Robert Dale Owen. Owen's amendment provided:

"Section 1. No discrimination shall be made by any State nor by the United States as to the civil rights of persons because of race, color or previous condition of servitude.

"Section 2. From and after the fourth day of July in the year 1876 no discrimination shall be made by any State nor by the United States, as to the enjoyment, by classes of persons, of the right of suffrage, because of race, color, or previous condition of servitude.

"Section 3. Until the fourth day of July, 1876, no class of persons, as to the right of any of whom to suffrage, discrimination shall be made by any State, because of race, color or previous condition of servitude, shall be included in the basis of representation.

"Section 4. Debts incurred in aid of insurrection or of war against the Union, and claims of compensation for loss of involuntary service or labor, shall not be paid by any State nor by the United States.

"Section 5. Congress shall have power to enforce by appropriate legislation, the provisions of this article."

See Owen, Political Results from the Varioloid, 35 Atzantic Monthry 660-70 (1875); JAAIES, op. cit. supra note 8, at 100-15.

01 Globe at 2265, 2286.

92 The first section was proposed in the Joint Committee by Bingham, on April 21. It was initially approved by a vote of 10 to 2. On April 25, it was dropped on a motion of Senator Williams, by a vote of 7 to 5. On April 28, however, Bingham proposed it again, as $\$ 1$, and it was approved by a vote of 10 to 3 . IKENDRICK 82-107. It essentially repeats the phraseology of H.R. No. 63 and its 
Section 1. No State shall make or enforce any law which shall abridge the privileges or immunities of citizens of the United States; nor shall any State deprive any person of life, liberty, or property without due process of law; nor deny to any person within its jurisdiction the equal protection of the laws.

Section 2. Representatives shall be apportioned among the several States which may be included within this Union according to their respective numbers, counting the whole number of persons in each State, excluding Indians not taxed. But whenever in any State the elective franchise shall be denied to any portion of its male citizens not less than twentyone years of age, or in any way abridged, except for participation in rebellion or other crime, the basis of representation in such State shall be reduced in the proportion which the number of male citizens shall bear to the whole number of such male citizens not less than twenty-one years of age.

We have already examined Stevens' remarks of May 8, concluding that he was essentially noncommittal with respect to the relationship of $\S 2$ to $\S 1$, and observing that he had previously disavowed any preemptive effect of H.R. No. $51 .{ }^{93}$ The other statement on which Mr. Justice Harlan relied so heavily was that of Bingham, and here, to be sure, there is the statement that $\S 2$ precluded the application of $\$ 1$ to voting rights: ${ }^{94}$

The amendinent does not give, as the second section shows, the power to Congress of regulating suffrage in the several States.

antecedent versions which the Joint Committee had considered since January 20, and which the House had been debating since February 13. See notes 46 and 66 supra. The major change is that Bingham's $\$ 1$ of H.R. No. 127 appears to address itself to the states, whereas H.R. No. 63 was a general grant of authority to Congress. This aspect of H.R. No. 63 met with the objection in the House that such a provision would seem to displace the general police power of the states. See remarks of Hale, GLOBE, at 1063-66, 1094-95.

The second section was proposed in the Joint Committee by Williams, on April 28 , and approved the same day. KENDRICK at 1022. It is closest to Sumner's proposal offered in the Senate on March 12. See text at note 89 supra. It differs essentially from H.R. No. 51 in but two respects: (1) the reduction of basis of representation is to be made for disfranchisement of adult male citizens, and not merely for disfranchisement because of race; (2) the reduction in basis is to be made ouly in proportion to the number disfranchised and not in proportion to the whole number of a class even if only one of the class is disfranchised. These modifications respond to objections to H.R. No. 51, earlier expressed in both Houses. See note 68 supra.

\footnotetext{
93 See text supra at notes 63-75. $\quad 94$ GLoBE at 2542; 377 U.S. at 593.
} 
The second section excludes the conclusion that by the first section suffrage is subjected to congressional law; save, indeed, with this exception, that as the right in the people of each State to a republican government and to choose their Representatives in Congress is of the guarantees of the Constitution, by this amendment a remedy might be given directly for a case supposed by Madison, where treason might change a State government from a republican to a despotic government, and thereby deny suffrage to the people.

In the whole context, including Bingham's earlier asseverations of January $25,{ }^{05}$ this is a puzzling statement. Does it mean that $\S 2$ limits $\$ 1$, but that it does not limit the broad authority over suffrage that Bingham had insisted Congress already possessed under Article I, $\$ 2$, and Article IV, $\$ 4$ ? If it limited the one, why did it not limit the other? Is it merely because of the close juxtaposition of $\S \S 1$ and 2 , but the textual separation of $\$ 2$ from earlier provisions in the Constitution? Is he maintaining, perhaps, that while earlier sections of the Constitution theoretically restrict state power over suffrage, $\S 2$ provides an additional, or even an exclusive, means for enforcing those restrictions? Or does he mean something else still, viz., that $\$ 2$ limits the application of $\S 1$ over voting rights, save with this exception, that where a state disfranchises so substantial a portion of its citizens that it ceases to become a republican form of government, $\S 1$ itself grants to Congress the power to correct that abuse?

Each of these may be a permissible construction of Bingham's remarks. Whatever their truly intended meaning, however, they were not the only remarks made during the debate in the House on H.R. No. 127. And, contrary to Mr. Justice Harlan's impression, it was not true that "every speaker on the resolution, with a single doubtful exception, assumed without question that, as Mr. Bingham said, supra, 'the second section excludes the conclusion that by the first section suffrage is subjected to congressional law.' "96

On May 5, Representative Phelps of Maryland spoke against the acceptability of $\S \S 1$ and 5 because they "covertly" authorized a law to impose "Negro suffrage and eligibility ... over the wliole country." ${ }^{37}$ On May 8, Representative Niblack, who opposed the Amendment, announced that he would shortly propose a new section to provide that "nothing ... shall be so construed as to authorize

05 See note 61 supra and accompanying text.

26377 U.S. at 599.

07 GLobe at 2398. 
Congress to regulate or control the elective franchise within any State. . . .98 He was immediately followed by Boyer of Pennsylvania, who also viewed $\S 1$ as a threat to state suffrage authority. ${ }^{90}$ Boyer felt that it was $\S 1$, rather than $\S 2$, that might indirectly secure political equality.

Finally, on May 10, the very day on which H.R. No. 127 was approved by the House by 128 to 37 , Representative Rogers of New Jersey dehivered some prophetic remarks on $\S 1$. Rogers is the "single doubtful exception" to whom Mr. Justice Harlan referred. Presumably he is "doubtful" only because he was a Democratic representative ardently opposed to the Radical Reconstruction Plan. On the other hand, he was also a member of the Joint Committee that had assembled H.R. No. 127, and thus his views may warrant more than passing attention. Speaking of $\S 1$, he said: ${ }^{100}$

What are privileges and immunities? Why, sir, all the rights we have under the laws of the country are embraced under the definition of privileges and immunities. The right to vote is a privilege. The right to marry is a privilege. The right to contract is a privilege. The right to be a juror is a privilege. The right to be a judge or President of the United States is a privilege. I hold if that ever becomes a part of the fundamental law of the land it will prevent any State from refusing to allow anything to anybody embraced under this term of privileges and immunities.

Stevens, who had not adverted specifically to suffrage under $\S 1$ when he outlined the scope of the Fourteenth Amendment on May 8 , soon sought to fulfill Rogers' prophecy about the right to vote as a "privilege" of citizenship. Less than two years later, on the heels of the ratification of the Fourteenth Amendment, Stevens delivered the following defense of a bill to preclude the states from denying the right to vote on account of race, relying on the language of $\S 1:^{101}$

Since the adoption of the fourteenth amendment ... I have no doubt of our full power to regulate the elective franchise, so far as it regards the whole nation, in every State of the Union, which, when tried, I hope, will be so formed as to be beneficial to the nation, just to every citizen, and carry

\footnotetext{
88 Id. at 2465.

99 Id. at 2467.

100 Id. at 2538 .
}

101 Cong. Globe, 40th Cong., 2d Sess. 1966-67 (1868). The bill Stevens endorsed was H.R. No. 126, introduced on July 11, 1867. Cong. Gxobe, 40th Cong., 1st Sess. 591 (1867). 
out the great designs of the framers of the Government, according to their views expressed in the Declaration of Independence. ...

The fourteenth amendment, now so happily adopted, settles the whole question and places every American citizen on a perfect equality so far as merely national rights and questions are concerned. ...

If by the amended Constitution every American citizen is entitled to equal privileges with every other American citizen, and if every American citizen in any of the States should be found entitled to impartial and universal suffrage with every other American in any State, then it follows as an inevitable conclnsion that suffrage throughout this nation is impartial and universal so far as every human being, without regard to race or color, shall be found concerned, and so far as it affects the whole nation.

In Stevens' retrospective view (which must, of course, be discounted to that extent), the Fourteenth Amendment had not merely left intact whatever power over suffrage Congress previously possessed. Through $\$ \$ 1$ and 5 , it had empowered Congress to invalidate state suffrage disqualifications based on race or color.

On the whole record, in any case, it seems quite impossible to conclude that there was a clear and deliberate understanding in the House that $\S 2$ was the sole source of national authority to protect voting rights, or that it expressly recognized the states' power to deny or abridge the right to vote. It may be closer to the marls to suggest that: (1) Section 2 left the disputed respective powers of the state and federal government over the franchise unaffected. (2) It was concerned with overcoming the apportionment formula of Article I, the better to assure the power of Congress to reduce southern representation in the House and Electoral College.

Whether this is the "correct" view or not, it is considerably more modest than that put forward by Stevens, its principal author, in 1868. It is far more modest, too, than the interpretation insisted upon by Boutwell in 1869. (Boutwell was a member of the Joint Committee that reported H.R. No. 51 and H.R. No. 127.) During House consideration of both bills, Boutwell had little to say respecting their effect on suffrage. On January 23, 1869, however, he defended the constitutionality of a bill guaranteeing Negro suffrage in language not dissimilar to that of the subsequently promulgated Fifteenth Amendment. Boutwell rested his bill on the bases of 
Article I, $\S 2$ and 4, Article IV, $\S 4$, and $\S \S 1$ and 5 of the Fourteenth Amendment. Speaking of these last two provisions, he said: ${ }^{102}$

If there were any doubt remaining in the mind of any person as to the power of Congress over this whole subject, as derived from the three provisions of the original text of the Constitution to which I have referred, I believe that every doubt must disappear upon an analysis of the fourteenth amendment. . . .

Mr. Nicholson. I desire to inquire whether, when the fourteenth article ... was under discussion in the Thirty-Ninth Congress, the gentleman himself, and other members of his party who took part in that discussion, did not concede the distinction between civil and political rights ... upon the class intended to be benefited?

Mr. BouTweLL. I have no recollection of anything of that sort, though it may be that some persons did make such a concession. I believe that gentlemen on the other side of the House generally claimed that it would confer such rights; and I cannot say but that some members on this side of the House may have disavowed that construction; but I was not one of them....

Then, sir, by the fifth section of the fourteenth article, Congress has power to enforce by appropriate legislation the provisions of the article. Does anybody doubt-in the presence of this ... unlimited power under the fourteenth article to legislate so as to secure to citizens of the United States the privileges and immunities of citizens of any one of the Statesdoes anybody doubt our duty? ...

I come now to the second section [of the Fourteenth Amendment], upon which I know reliance will be placed by the opponents of the bill. ...

If gentleman will consider these two sections together they will see how entirely in harmony they are with each other, and how wholly unsupported is the doctrine that there is in this second section any concession to a State to abridge or deny to a citizen the right to vote. By the second section there is a political penalty for doing that which in the first section it is declared the State has no right to do....

It is here provided that there shall be no abridgement of the privileges and immunities of citizens; and in the second section there is a penalty provided for a State that disregards the inhibition. We were then acting in the presence of the fact that many States of the Union were doing that which the first section declared they had no right to do. It was

102 Cong. Globe, 40th Cong., 3d Sess. 558-60 (1869). 
uncertain when Congress would exercise the power conferred by the fifth section of the fourteenth amendment, and in order that the States should not take advantage of their own wrong during the period while Congress might be inactive a penalty was provided. We knew that Kentucky, Maryland, and Delaware were doing what they were inhibited from doing by the first section of the article, and we said that they should suffer in representation for so doing. Power was given to Congress to remedy this evil, and that power Congress is now called upon to exercise. . . .

Mr. EldRIDGe. . . . The question I desire to put is this: whether there is not in that amendment a distinct recognition of the existence of the power to regulate suffrage in the States themselves?

Mr. Boutwell. Oh, no; not the least. . . . If the right to vote for certain officers be denied or abridged, then certain political consequences follow; but in the first section there is a distinct declaration that this cannot lawfully be done. We only recognized the existing facts. We knew there were some States in which the wrong existed. It might require time before Congress could exercise its powers under the fifth section, and the country meant to say that while this state of things continued-a state of things unjust and contrary to the Constitution-the States should not have the benefit of their wrongdoing.

In respect to the Senate debate in May, 1866, on H.R. No. 127, it is quite true, as Mr. Justice Harlan noted, that Senator Howard said of $\$ 2$ that it "does not recognize the authority of the United States over the question of suffrage in the several States at all," and that it "leaves the right to regulate the elective franchise still with the States, and does not meddle with that right." ${ }^{\text {103 }}$ It should be noted, however, that these remarks do not assert that $\$ 2$ precludes the exercise of any other constitutional power Congress possesses over the franchise, i.e., Howard did not take the position that $\$ 2$ establishes the exclusive authority of the states over suffrage. It is perfectly unremarkable that he would observe that $\$ 2$ did not "recognize" the authority of the United States over suffrage, if by that he meant only what in fact he said: that $\$ 2$ itself did not "establish" or "grant" any new national authority over suffrage.

It may still be the more reasonable inference, however, that in saying that $\$ 2$ "leaves the right to regulate the elective franchise still

103 GLOBE at 2766. 
with the States" and that it "does not recognize the authority of the United States over the question of suffrage," Howard meant that it precluded any other provision from being regarded as establishing any national authority over suffrage. If so, however, his position nuust simply be construed as contrary to the position asserted by Fessenden earlier, that H.R. No. 51, the forerunner of $\S 2$, had no such effect. And it is no particular source of wonder that Howard would not have agreed with Fessenden, because on March 9, the day Fessenden was most emphatic respecting the noncommittal character of H.R. No. 51, Howard was absent from the Senate. ${ }^{104}$ Moreover, his own feeling that the states could regulate the franchise exclusively as they saw fit stands in contrast with that of Yates, Wade, and Sumner in the Senate, and at least nine members of the House, all of whom had declared at the time that the states had no such exclusive prerogative.

The sum of the record respecting $\S 2$, then, seems insufficient to support an inference that even though its language is utterly noncommittal on whether Congress could exercise authority fiowing fron other constitutional provisions to broaden the franchise, it was nonetheless clearly understood at the time to preempt any such authority or preclude the exercise of that authority. Whether such authority might have been elsewhere in the Constitution or in the Fourteenth Amendment itself, in $\$ \S 1$ and 5, must consequently be a function of the language and understanding of those sections-an issue not foreclosed by $\$ 2$.

\section{The Open Texture of Section One}

"Should not the search for congressional purpose ... properly be twofold? One inquiry should be directed at the congressional understanding of the immediate effect of the enactment on conditions then present. Another should aim to discover what if any thought was given to the long-range effect, under future circumstances, of provisions necessarily intended for permanence."105 Professor Bickel's disarming question respecting "original understandings" in general applies as nuch to the issue of state power over suffrage as it did to state power over segregation. For there was, before the Thirty-ninth Congress, an even clearer choice of alternatives on

104 Id. at 1280 .

105 Bickel, supra note 11 , at 59. 
this issue than on the dimly perceived issue of per se racial segregation, about which Professor Bickel was writing. The first alternative was put forward by Boutwell of Massachusetts on December 13, 1865 , very early in the first session of the Congress. It was to propose an amendment "that no State shall make any distinction in the exercise of the elective franchise on account of race or color." $106 \mathrm{Or}$, on the assumption that Congress already possessed the necessary authority, to attempt the same task by statute, as repeatedly urged by Senator Sumner from December 20 on. ${ }^{107}$ The same type of proposal, again in the form of an amendment, was proposed by Senator Henderson of Missouri: ${ }^{108}$ "No State, in prescribing the qualifications requisite for electors therein shall discriminate against any person on account of color or race." This alternative, boldly to confront the limited and specific issue of equal suffrage for Negroes alone, and to dispose of it by action immediately invahidating contrary state laws, was supported by a number of Senate Radicals, including Yates, Sumner, Wade, Williams, Henderson, Howe, Poland, Pomeroy, Brown, and Chandler. ${ }^{109}$ It was deliberately entertained by the Joint Committee when, on January 12, the committee considered the following proposed amendment: ${ }^{110}$

Representatives and direct taxes shall be apportioned among the several States within this Union, according to the respective numbers of citizens of the United States in each State; and all provisions in the Constitution or laws of any State,

108 GLOBE at 49.

$$
107 \mathrm{Id} \text {. at 92, 674, 765, 1228-31, } 1288 \text {. } \quad 108 \mathrm{ld} \text {. at } 702 .
$$

109 On March 9, Yates proposed the following substitute for H.R. No. 51: "That no State or Territory of the United States shall by any constitution, law, or other regulation whatever, heretofore in force or hereafter to be adopted, make or enforce in any way, or in any manner recognize any distinction between citizens of the United States or of any State or Territory, on account of race or color, or previous condition of slavery; and that hereafter all citizens, without distinction of race, color, or previous condition of slavery, shall be protected in the full and equal enjoyment and exercise of all their civil and political rights, including the right of suffrage." By a vote of 7 to 38, the amendnent failed. Yates, Sumner, Wade, Brown, Chandler, Pomeroy, and Williams voted for it. Id. at 1287.

The same day, Sumner attempted to amend H.R. No. 51 by substituting: "And the elective franchise shall not be denied or abridged in any State on account of race or color." His amendment lost on a vote of 8 to 38 . Brown, Henderson, Howe, Poland, Pomeroy, Sumner, Wade, and Yates voted for it. Id. at 1288.

110 See note 46 supra and accompanying text. 
whereby any distinctions made in political or civil rights or privileges on account of race, creed or color, shall be inoperative and void.

The decision was made, however, not to propose a limited, singlepurpose amendment; not to advertise the particular issue of Negro suffrage and to dispose of it through a provision instantly invalidating the laws of all states where equal suffrage regardless of race was denied. The reluctance of the Republicans bluntly to dispose of the issue in this fashion is readily explainable; there was not sufficient prospect that the necessary number of states would ratify such an amendment.

There were, in 1866 , but five states in the nation that permitted Negroes to vote on equal terms with whites: Maine, Massachusetts, New Hampshire, Rhode Island, and Vermont. Together, these states contained a mere 6 per cent of the northern Negro population. New York also permitted Negro suffrage, but only for those possessed of at least a $\$ 250$ freehold estate, an added "qualification" that whites were not obliged to satisfy. No other state permitted Negroes to vote, regardless of qualification. Moreover, in late 1865 , shortly before the Thirty-ninth Congress convened, Connecticut, Minnesota, and $W$ isconsin voted down impartial suffrage by popular referendum. ${ }^{111}$ The Territory of Colorado defeated a referendum for impartial suffrage by a wide margin in September, 1865, and was, nevertheless, admitted to the Union by Congress in 1866.112

The admission of Colorado, with its ban on Negro voting, followed the admission of Nevada, which had a similar ban, and was, in turn followed by the readmission of Tennessee on July $24,1866 .{ }^{113}$ The readmission of Tennessee was accomplished, moreover, with complete awareness that its general assembly had, on June 5, 1865, restricted the franchise to white males only. ${ }^{114}$ Indeed, all these facts were well known to the Congress, and were gleefully recited by some of the Democrats who challenged the Republicans to dare to make an issue of Negro suffrage. ${ }^{115}$ It was also true that after 1860

\footnotetext{
111 See Guletre, op. cit. supra note 8; James, op. cit. supra note 8, at 13; Murray, Re-examination of the Roots of Racial Crisis (1965). 
the Republican platforms had discreetly skirted the issue of Negro suffrage.

All these things and more had a conspicuous and significant influence on the Thirty-ninth Congress. On June 22, 1865, for instance, Senator Howard had written to Sumner, saying:116 "The Negro must vote. ... It is our only security and the only means of making emancipation effectual. He must vote. . . ." He was confident of Congress' power to extend the franchise at least in the South, and he urged that it be done "at the earliest possible day so as to put an end to this executive reconstruction which seems likely to restore slavery and bring rebels into congress." Yet, in reporting the consolidated Fourteenth Amendment, the same Senator Howard was to insist on May 23, 1866, that "the first section of the proposed amendment does not by itself give to either of these classes the right of voting." 117 In reporting his conversation with Stevens, leading to Stevens' willingness to bring his proposed amendment to the attention of the Joint Committee on April 21, 1866, Robert Dale Owen quoted Stevens as saying: ${ }^{118}$ "We haven't a majority, either in our committee or in Congress, for immediate suffrage; and I don't believe the states have yet advanced so far that they would be willing to ratify it." Stevens reiterated his lack of confidence in the willingness of the states to ratify any proposal immediately to enfranchise the Negro. While he insisted that H.R. No. 51 "grants [the states] no right" of disfranchisement, he declared that the states would not adopt any proposal stronger than the one he was offering. ${ }^{119}$ Typical, too, was the remark of Senator Wilson, speaking in favor of H.R. No. 51 on March 8. Like Stevens, le denied that H.R. No. 51 would preempt any power Congress might otherwise have to regulate the franchise. He favored an enfranchising amendment but would not support any proposed aniendment clearly and imnediately designed by itself to enfranchise the Negro, because it could not be adopted. 120

In addition to those who declared against such a proposal on the grounds of expediency, there were those who placed their unwillingness to act on a more lofty basis, namely, that the states should be free to decide this question for themselves, as many had believed

110 Quoted in JAMES, op. cit. supra note 8, at 13.

117 Glone at 2766.

119 Globe at 536.

118 Owen, supra note 90 , at 662 .

$120 \mathrm{Id}$. at 1256. 
they were constitutionally entitled to do. A representative combination of reasons appears in the remarks of Senator Doolittle of Wisconsin, in the course of arguing in favor of admitting Colorado in spite of the fact that Negroes were not allowed to vote. After declaring that he personally favored equal Negro suffrage, Doolittle added: ${ }^{121}$

... there was another thing that I advocated, and it was this: that each State had a right for itself to determine the question, and that the Federal Government had no right or constitutional power to impose on a State negro suffrage; that the right of a State to determine that question for itself was one of the reserved rights of every State, under the Constitution. ...

The question the gentleman asked was, whether the states will accept a proposition to amend the Constitution giving negro suffrage. I answer no, sir, they will not. Join the issue as soon as you please here or elsewhere, and out of New England there are not three States in this Union, neither Nevada nor Colorado, nor any of the new States or the old States that will vote for an amendment of the Constitution of the United States by which negro suffrage shall be imposed upon the States.

There were, too, expressions of regret, when the consolidated amendment was before Congress, that it did not establish broad suffrage in the United States. Representative Garfield with a great rhetorical flourish complained of the absence of such provisions, but concluded pragmatically: ${ }^{122}$ "But I am willing, as I said once before in this presence, when I cannot get all I wish to take what I can get."

With all of this, then, the alternative of proposing a blunt amendment banning Negro disenfranchisement was emphatically rejected. With all of it, too, the case can safely be made that there was an original understanding that $\S 1$ of the proposed Fourteenth Amendment would not itself immediately invalidate state suffrage laws severely restricting the right to vote. With all of it, however, we cannot safely declare that there was also a clear, uniform understanding that the open-ended phrases of $\S 1$-"privileges or immunities of citizens of the United States . . . life, liberty, or property ... the equal protection of the laws"-would foreclose a different application in the future. Most especially is this so to the extent that 
legislative action to invalidate state laws barring Negroes from voting was avoided as a matter of expediency, i.e., from fear tliat such an amendment would not be ratified and that its Republican sponsors would be turned out of office at the next congressional election.

The question whether the original understanding was itself intended equally to bind the indefinite future becomes more lively when we note that the Thirty-ninth Congress did not adopt a second alternative: to accomplish specific, narrowly defined ends by producing an equally specific and narrowly defined amendment that, by clear language, could never be applied to suffrage. The failure to pursue that alternative, moreover, could scarcely have been inadvertent. After all, Stevens himself had spoken of equal protection in so broad a fashion that the ultimate reach of the clause could not safely be foreseen: ${ }^{123}$

Whatever law protects the white man shall afford "equal" protection to the black man. Whatever means of redress is afforded to one shall be afforded to all. Whatever law allows the white man to testify in court shall allow the man of color to do the same. ... Unless the Constitution should restrain them those States will all, I fear, keep up this discrimination, and crush to death the hated freedmen.

Several of the Democrats declared, moreover, that the Privileges and Immunities Clause would eventually be applied to suffrage. In spite of this, the Republicans declined to limit the language of $\$ 1$ to avoid such an application, or to add a qualifying provision such as that suggested by Niblack, that "nothing . . . shall be so construed as to authorize Congress to regulate or control the election franchise within any State."

All this might readily be passed off as a mere unwillingness to clutter the Amendnient with unnecessary language to overcome a frivolous and unfounded objection by the Democrats, and as not in the least detracting from an understanding that nothing in $\$ 1$ could ever apply to suffrage. Yet, there is such a striking difference between the Republicans' response to criticisms of the open text of the Fourteenth Amendment and their response to identical criticisms of the Civil Rights Act, adopted in the same session, that the question is left open to a different view.

For one thing, it would be inaccurate to assume that no one had

123 See note 69 supra and accompanying text. 
any reason to take seriously predictions that the enabling clause, $\$ 5$ of the Fourteenth Amendment, in combination with the broad phraseology of $\S 1$, might someday be used to reach suffrage. Section 5 is identical in language to $\$ 2$ of the Thirteenth Amendment, and this same session of Congress had based its authority to enact the Civil Rights Act on the proposition that that Act was "appropriate legislation" to enforce the mere ban on "slavery" in $\$ 1$ of the Thirteenth Amendment. ${ }^{124}$ The Civil Rights Act, on the bare strength of the Thirteenth Amendment, had gone leagues beyond forbidding laws keeping persons in actual bondage. ${ }^{125}$ It had given Negroes who had never been slaves as well as those who were no longer slaves equal rights to make and enforce contracts, to acquire, use, and dispose of property, to enjoy equal status in all legal proceedings, and to enjoy equal protection of law enforcement against anyone attempting to interfere with these equal rights. It made it a federal criminal offense for anyone acting under law or custom to interfere with these rights. It provided for removal to the federal courts of cases in which the state courts might fail to recognize these rights. It provided for federal troops to safeguard these rights, and it provided for a substantial list of federal civil remedies against private and official interference with these rights. In short, the Thirtyninth Congress rehed upon the open text of the Thirteenth Amendment (by no means as open, however, as that of the Fourteenth Amendment) to enact what were the precursors of civil rights legislation still on the books. ${ }^{126}$ Thus, the same Congress that adopted the open text of $\S 1$ of the Fourteenth Amendment and combined it with the legislative enforcement provision of $\$ 5$ had-in the same session-already used the less "permissive" text of the Thirteenth Amendment to render an extraordmarily expansive "understanding" of what was forbidden by the ban on slavery. It would be quite unreasonable to assume, therefore, that the complaints of the Democrats against the even more vaguely worded provisions of $\S 1$ in the Fourteenth Amendment were baseless. And, fresh from their own

124 Senator Trumbull, the author of the Civil Rights Act, explicitly rested its constitutionality on the Thirteenth Amendment. GLOBE at 474. See also id. at 602, 1151, 1159, 1268-69.

${ }_{125}$ Act of April 9, 1866, c.31, 14 Stat. 27. The ten long sections of the Act are also printed at Grobe, App. 315-16.

126 See 42 U.S.C. $\$ \$ 1981,1982,1987-92$ (1964); 18 U.S.C. $\$ 242 ; 28$ U.S.C. $\S 1443 ; 10$ U.S.C. $\$ 332$. 
experience in developing new applications of the Thirteenth Amendment on the very heels of its ratification, the Radicals could scarcely have failed to foresee that the still broader contours of the Fourteenth Amendment would offer even greater possibilities for the future.

There is still more significance to the concurrent history of the Civil Rights Act. As the bill (S. No. 1) was introduced on January 5 by Senator Trumbull and reported to the Senate from his own Judiciary Committee on January 12, the particular specification of rights to be protected by the bill was preceded by a broader and more general clause: ${ }^{127}$

There shall be no discrimination in the civil rights or immurities among the inhabitants of any State or Territory of the United States on account of race, color, or previous condition of slavery; but the inhabitants of every race and color, without regard to any previous conditions of slavery or involuntary servitude, except as a punishment for crime whereof the party shall have been duly convicted, shall have the same right to make and enforce contracts, to sue, be parties, and give evidence, to inherit, purchase, lease, sell, hold, and convey real and personal property, and to full and equal benefit of all laws and proceedings for the security of person and property, and shall be subject to like punishment, pains, and penalties, and to none other, any law, statute, ordinance, regulation, or custom to the contrary notwithstanding.

$U_{p}$ to a point, the subsequent legislative history of the Civil Rights Act was entirely parallel to the treatment of $\$ 1$ of the Fourteenth Amendment. Thus, in leading off the discussion on January 29, Trumbull declared that his bill had "nothing to do with political rights." ${ }^{128}$ In arguing for the bill on February 1, Senator Henderson expressed his understanding that the bill would not admit Negroes to the ballot box. ${ }^{129}$ The following day, Trumbull again declared: 120 "The bill is applicable exclusively to civil rights. It does not propose to regulate the political rights of individuals; it has nothing to do with the right of suffrage, or any other political right...."

Saulsbury of Delaware, however, was not satisfied with these assurances. He thought that the phrase "civil rights" in the opening

127 GLOBE at 129, 211. See also id. at 474.

$128 \mathrm{Id}$. at $476 . \quad 128 \mathrm{Id}$. at $571 . \quad 130 \mathrm{ld}$. at 599. 
sentence was susceptible of embracing the right to vote and that the provision "[there] shall be no discrimination in the civil rights ... on account of race" might be taken as an attempt to strike down state laws restricting suffrage to whites. To clarify the matter, he proposed to amend the bill by adding, after the words "civil rights," "except the right to vote in the States." His amendment lost 12 to 33, after Trumbull opposed the amendment: ${ }^{131}$

... that is a political privilege, not a civil right. This bill relates to civil rights only, and I do not want to bring up the question of negro suffrage in the bill. I hope the Senator will not persist in any such amendment.

Thus far, the treatment of the open texture of the civil rights statute was the same as that respecting $\$ 1$ of the Fourteenth Amendment: i.e., in spite of complaints that it might lead to future protection of voting rights, the proponents refused to adopt an amendment to preclude that effect, even while denying that such an effect was intended. In the House, however, there was a different result. In spite of declarations that the bill would not affect voting rights, ${ }^{132}$ even Bingham was not satisfied. He moved to strike out the opening general phrase, partly because he thought the broad phrase "civil rights" embraced "political rights," and he doubted both the wisdom and constitutionality of legislating with respect to the franchise: ${ }^{133}$

I submit with all respect that the term "political rights" is only a limitation of the term "civil rights," and by general acceptation signifies that class of civil rights which are more directly exercised by the citizen in connection with the government of his country. If this be so, are not political rights all embraced in the term "civil rights," and must it not of necessity be so interpreted?

Shellabarger of Ohio immediately "defended" the bill, saying that the civil rights to be protected were only those subsequently named in the bill itself. ${ }^{134}$ Then, an attempt by Bingham to amend the bill by deleting the phrase "civil rights" was defeated, but a vote to recommit the bill to the House Judiciary Committee carried immediately. ${ }^{\mathbf{1 3 5}}$

131 Id. at 606 .

132 See the remarks of Representatives Wilson and Thayer on March 1, and Wilson and Windom on March 2, 1866. GLoBE at 1117, 1151, 1159.

133 Id. at 1291 . $\quad 134$ Id. at 1293 . $\quad 135$ Id. at 1296. 
On March 13, Wilson of Iowa reported back an amended version. The amendment would delete the whole open-ended phrase, "there shall be no discrimination in civil rights or immunities among citizens of the United States in any State or Territory of the United States on account of race, color, or previous condition of slavery." This, of course, was the phrase previously objected to on the ground that it might include the right to vote. Wilson necessarily had these objections in mind in explaining the committee's reason for the proposed deletion. He declared: 138 "Some gentlemen were apprehensive that the words we propose to strike out might give warrant for a latitudinarian construction not intended." The amendment was approved without further debate; the bill was then passed in the House, concurred in by the Senate, and subsequently approved by two-thirds in each House over the President's veto. ${ }^{137}$ In the debate on the bill following the President's veto, it was again pointed out that the phrase "civil rights" had been dropped in consideration of Bingham's objections that it might have been misunderstood to include voting rights. ${ }^{138}$

The ultimate disposition of the "contest" over the ambiguity of the Civil Rights Act, a statute based on the Thirteenth Amendment and designed to be enforced immediately, is thus in striking contrast with the response of the Radicals to the same contest over the open text of the proposed Fourteenth Amendnient and its future-looking $\S 5$. In the former, they responded by deleting the ambiguous phrase and by accepting the alternative of enacting a limited bill, specifically enunerating the particular interests that would receive equal protection. In the latter, notwithstanding the still broader phraseology of $\S 1$ and equally vigorous complaints that it might eventually be applied to voting, no concession was made. The Civil Rights Act was, of course, a statute: a law not expected to "endure for ages to come." The Fourteenth Amendment was something else again.

From all this, the basis for deriving the original understanding of $\S 1$, "under future circumstances, of provisions necessarily intended for permanence," $" 130$ is perhaps about the same for suffrage as that which Professor Bickel determined for per se segregation: ${ }^{140}$

\footnotetext{
136 Id. at 1366.

137 Id. at $1367,1413,1438,1679,1809,1861$.

138 Id. at 1837.

139 McCulloch v. Maryland, 4 Wheat. 316, 415 (1819).

140 Bickel, supra note 11 , at 62 .
} 
They [the Moderates] could go forth and honestly defend themselves against charges that on the day after ratification Negroes were going to become white men's "social equals," marry their daughters, vote in their elections, sit on their juries, and attend schools with their children. The Radicals ... obtained what early in the session had seemed a very uncertain prize indeed: a firm alliance, under Radical leadership, with the Moderates in the struggle against the President, and thus a good, clear chance at increasing and prolonging their political power. In the future, the Radicals could, in one way or another, put through such further civil rights provisions as they thought the country would take, without being subject to the sort of effective constitutional objections which haunted them when they were forced to operate under the thirteenth amendment.

In retrospect, Professor Bickel's analysis is even more attractive than when he first offered it. For the primary object of $\S 2$ of the Fourteenth Amendment may now be seen as a significant complement to the compromise achieved in $\S 1$ : as an additional means developed by the Republicans to increase and prolong their political power, and not as an exclusive substitute for putting through such further civil rights provisions (including voting) as they thought the country would take in the future.

\section{The Irrelevance of Section Two to Malapportionment}

Reynolds $v$. Sims was one of several cases holding that a particular state law prescribing the method "of constituting state legislatures" was invalid under the Equal Protection Clause. Carrington $v$. Rash was a case holding that a particular state law prescribing voter qualifications was invalid under the same clause. In the latter case, Mr. Justice Harlan counseled the Court that its prior determination to apply the Equal Protection Clause to issues of malapportionment did not warrant an extension of the same clause to the separate issue of voter qualifications. ${ }^{141} \mathrm{He}$ thought it significant, moreover, that the Court failed to cite any of its reapportionment decisions as precedents for its action in Carrington v. Rash.

My purpose in this concluding section is to suggest something similar with respect to Mr. Justice Harlan's use of history. The suggestion is that the legislative history on which he relied in Reynolds v. Sims was serviceable, if at all, only in Carrington v. Rash, i.e., that

141380 U.S. at 98 , 
the "original understanding" that he found conclusive had only to do with exclusive state power over suffrage qualifications and that it need not be extended in any event to the separate issue of malapportionment. Especially is this so to the considerable extent that the original understanding was based on the allegedly preclusive effect of $\$ 2$.

So far as an original understanding of the relevance of the Equal Protection Clause to issues of state legislative malapportionment is concerned, all one can safely conclude from the congressional history of the Fourteenth Amendment is that there was almost no mention of the subject. ${ }^{142}$ The record in regard to malapportionment is even less readily construed against the application of the Amendment in accordance with its unqualified language than with regard to countless other issues since swept within the broad normative standard of equal protection. ${ }^{143}$

Even assuming that the clause was understood as not adding any national authority over voting qualifications, that understanding is not readily transferable by analogy to problems of malapportionment for at least two reasons. First, it is at least arguable that the "right" of the states affected by requiring the roughly equal apportionment of representatives within a state according to population is neither so basic nor the same kind as the "right" to prescribe voter

\footnotetext{
142 But $c f$. the remarks of Blaine in opposition to H.R. No. 51 (although he subsequently voted to approve it). Globe at 377,538 . Blaine felt that if the number of voters were made the basis of apportioning representatives among the states, each state would then apportion its representatives according to the distribution of voters within the state-effectively leaving areas populated by nonvoters without representation (and not merely without a vote in the choice of "their" representatives). To these and other objections, however, Bingham immediately replied: "I apprehend that no possible amendment that can be suggested to the Constitution of the United States on this subject will answer the purpose unless it is followed by further legislation." Grobe at 377. Even Blaine's remarks were directed only to the apportionment of congressional, rather than state, representatives. The brief exchange between Blaine and Bingham occurred on January 23,1866 , three weeks before the original version of $\$ 1$ (H.R. No. 63) was reported in the House.

143 See, e.g., McLaughlin v. Florida, 379 U.S. 184 (1964); Schneider v. Rusk, 377 U.S. 163 (1964); Morey v. Doud, 354 U.S. 457 (1957); Griffin v. Illinois, 351 U.S. 12 (1956); Brown v. Board of Educ., 347 U.S. 483 (1954); Nixon v. Herndon, 273 U.S. 536 (1927); Strauder v. West Virgima, 100 U.S. 303 (1880). See also Harris, op. cit. supra note 11, at 82-129; Kurland, supra note 9; Kellett, supra note 14; Tussman \& tenBroek, The Equal Protection of the Larws, 37 CalrF. L. REv. 341 (1949).
} 
qualifications. The latter question goes directly to the issue of who shall decide what persons are sufficiently qualified or fit to participate in affairs of state government at all. To say that certain varieties of malapportionment are within the Equal Protection Clause, on the other hand, is to say only that among the enfranchised elite, all of whom the state itself has found to be fully qualified to participate in affairs of government, no invidious distinctions shall be permitted. The states may be as capricious as they please in withholding the ballot but not in perpetuating elites within the elite. The latter practice is a severe aggravation of the former one and surely need not be placed beyond correction on the strength of a doubtful concession originally made concerning only the former, a concession not even carried into the language of the Constitution.

The issue of malapportionment also differs from that of voter qualifications in terms of the particular constitutional clause which $M r$. Justice Harlan relied upon as expressly reserving the latter subject to the states alone. His argument in significant part was that $\$ 2$ expressly recognized the power of states to deny the right to vote and that it precluded the application of any other section by providing an exclusive remedy of its own, namely, a proportional reduction in a state's basis of congressional representation. Granting that this may arguably be so with respect to outright denials of the right to vote, is it equally so with respect to partial disfranchisement through malapportionment? Does $\$ 2$ propose the same exclusive (and preclusive) remedy here as well?

Mr. Justice Harlan's history fails to suggest that it does. Again, no more than anyone else did he uncover any discussion of the relevance of $\$ 2$ to malapportionment. He did, however, italicize that part of $\S 2$ which declares that the basis of representation shall be reduced when the right to vote is denied "or in any way abridged,"144 and this may be thought to include instances of malapportionment. With a little stretching, the language might suggest that the right to vote is "abridged" when the district in which a given voter resides is malapportioned so that his diluted vote is of less than average strength. Accordingly, Congress should regard all underrepresented state voters as having their votes denied or abridged and should exclude them from the population basis of the state for purposes of apportioning congressional representatives.

144377 U.S. at 593. 
Correspondingly, the provision for this exclusive remedy in $\$ 2$ precludes consideration of malapportionment cases under the Equal Protection Clause of $\$ 2$.

All this might be plausible, even granting that malapportionment was not discussed in the Thirty-ninth Congress. It becomes less plausible, however, once the congressional history of the critical phrase, "or in any way abridged," is canvassed and once it becomes clear that that phrase had nothing at all to do with malapportionment.

The word "abridged" was included in every draft of $\S 2$, beginning with H.R. No. 51 as reported by Stevens on January 22, 1866. H.R. No. 51, it will be recalled, provided for a reduction in the basis of representation only when the right to vote was "denied or abridged" because of race or color. The particular significance of "abridged" was not specifically discussed, but it may have been the result of a colloquy among Representatives Stevens, Jenckes (Rhode Island), and Farnsworth (Illinois), on January 23. Jenckes raised the question whether a reduction in the basis of representation would be called for if a state substituted a property qualification for one based on race or color. Stevens replied that such a qualification, being impartial so far as race or color was concerned, would not be affected by his bill. Then Farnsworth cut in: ${ }^{145}$ "Suppose the State of South Carolina should provide by law that no negro should hold real estate." To which Stevens replied: "Then the amendment operates." Thus, Stevens thought that the right to vote was being "denied or abridged" because of race or color when a state had one statute prescribing a particular qualification on some basis other than race or color and another statute making it impossible for Negroes to satisfy the "neutral" qualification. Obviously, however, the conversation is entirely in terms of how to determine who has been completely demed the right to vote, and not how weighty or valuable a fully qualified voter may have.

When H.R. No. 127, the packaged amendment, was debated in the Senate in May, specific debate focused on "abridged," and ultimately resulted in a substantial change in $\$ 2$. On May 23, Senator Howard explained the new, consolidated Fourteenth Amendment as reported to both houses on April 30. Section 2 of the Amendment as proposed provided: ${ }^{146}$ 
Representatives shall be apportioned among the several States which may be included within the Union, according to their respective numbers, counting the whole number of persons in each State, excluding Indians not taxed. But whenever in any State, the elective franchise shall be denied to any portion of its male citizens not less than twenty-one years of age, or in any way abridged, except for participation in rebellion or other crime, the basis of representation in such State shall be reduced in the proportion which the number of male citizens shall bear to the whole number of nale citizens not less than twenty-one years of age.

After a brief discussion of this section, Howard was interrupted by Stewart of Nevada: ${ }^{147}$

Mr. Stewart. I wish to call the attention of the Senator to the word "abridged" before he passes from that branch of the subject. I should like to understand the operation intended by that expression.

Mr. HowARD. The word "abridged" I regard as a mere intensive, applicable to the preceding sentence. . . . I suppose it would admit of the following application: a State in the exercise of its sovereign power over the question of suffrage might permit one person to vote for a member of the State Legislature, but prohibit the same person from voting for a Representative in Congress. That would be an abridgment of the right of suffrage; and that person would be included in the exclusion, so that the representation from the State would be reduced in proportion to the exclusion of persons whose rights were thus abridged.

Thus, it was Howard's view (from which no one dissented) that "the elective franchise" referred to in $\$ 2$ included the right to vote both for federal and state officers. The denial of the right to vote for any one of these officers would be regarded as an abridgment of the right to vote for them all, bringing the penalty provision into play.

This explanation, while perfectly sensible, brought up a new problem. It was now clear that the phrase "elective franchise" meant to protect the right to vote for offices in addition to representatives, but it remained unclear what other offices were included. Would it mean that the "elective franchise" would be "abridged," for instance, if a male citizen could vote for all significant federal and state offices, and yet not be permitted to vote for, say, county supervisor? Just what offices were included in the "elective franchise?"

147 Id. at, 2767. 
The issue was expressly drawn in the Senate when, on June 7, Senator Williams of Oregon (a member of the Joint Committee) proposed a substitute for $\$ 2$ providing: ${ }^{148}$ “. . . But whenever the right to vote at any election held under the Constitution and laws of the United States, or of any State, is denied to any of the male inhabitants of such State, being twenty-one years of age and citizens of the United States, or in any way abridged. ..." Williams' substitute was immediately approved without discussion, by a voice vote. At once, however, Senator Henderson of Missouri called for a division, urging the defeat of Williams' substitute because of the ambiguity of the new language: ${ }^{149}$ " $W$ ill it apply to the election of city officers under the amendment as it now stands?"

Mr. Fessenden. I think it would to municipal officers.

Mr. Henderson. Then why would it not apply to the election of a township officer, because that is still larger?

Mr. CLARK. Is it a political office? I do not think a school director is.

After more discussion of this type, Senator Grimes moved that the Senate adjourn in order to provide an opportunity for further clarification of the types of office meant to be affected by $\S 2 .{ }^{150}$ The following day, the issue was taken up by Senator Johnson of Maryland: ${ }^{161}$

In all the States there are elections of a municipal character that are regulated by law, and in which the franchise is different from that which prevails in the general elections of the State; and the consequence would be that where any persons who are twenty-one years of age are denied the right to vote the basis of representation is to be lessened in the proportion that the number excluded shall bear to the whole number falling within the class. . . . What I suggest, therefore, to the honorable member and to the Senate is, that the phraseology of this amendment, if it is to prevail, shall be so changed as to leave it beyond doubt that all that is meant is to except out of the whole number of inhabitants of the age of twentyone years or upward, who are citizens of the State, those who are denied the right to vote at any State election, as contradistinguished from any municipal election. Without such a qualification I am sure it will lead to very serious doubts, and it may lead, as those doubts may be resolved, to a very serious diminution of the representation of several of the States.

\footnotetext{
148 Id. at 3010 .

$150 \mathrm{Id}$. at 3011.

149 lbid.

151 Id. at 3028-29.
} 
Senator Williams immediately responded to Johnson's criticism: ${ }^{152}$

I will state here that the amendment which I offered . . . is subject to some verbal criticism which is plausible, but I do not think well founded. I find it so easy to remove the difficulty that, upon consultation with the committee and other friends of the measure, I propose to strike out certain words and substitute others which will, perhaps, obviate some of the objections of the Senator.

... I propose to modify it by striking out the wordsbut whenever the right to vote at any election held under the Constitution and Laws of the United States or of any State-

And to insert the words:

But when the right to vote at any election for the choice of electors for President and Vice President of the United States, Representatives in Congress, the executive and judicial officers of a State, or members of the Legislature thereof.

Specifying particularly the officers for which these people must be allowed to vote in order to be counted.

Mr. Johnson. That removes some of the objections to which I supposed the original proposition was subject; and that shows how exceedingly cautious we should be in these constitutional amendments. . . .

Later, still on June 8, Williams' amendment was approved by the Senate, 31 to 11, as a separate amendment unentangled with any others. Among those voting for it were Johnson, Stewart, Howard, and Williams. ${ }^{153}$ When the Senate version was returned to the House, Williams' version of $\S 2$ was approved along with the rest of the Amendment, without particular discussion of his modification, by 120 to 32 , on June $13 . .^{154}$

Thus, the exclusive and express understanding of the phrase that superficially lends itself to an interpretation that it contemplated "abridgment" by dilution of one's vote through malapportionment in fact was completely different. It was, rather, that the right to vote protected by $\$ 2$ included the right to vote for all six specified groups of offices and that complete disqualification from voting for

\section{Ibid.}

153 Id. at 3040-41. The whole proposed amendment was then approved. Id. at 3042.

154 Id. at 3149. 
any one of the six would constitute an "abridgment" of the right to vote for them all, for representational reduction purposes.

There is, then, no evidence that $\$ 2$ was applicable to abridgments of the right to vote resulting from malapportionment of state legislatures. Whatever the arguable preclusive effect of $\$ 2$ respecting the power of states to determine voting qualifications unhampered by any restriction otherwise implied by the Equal Protection Clause, no such effect was understood regarding malapportionment. And $\S 2$ aside, there was no express understanding one way or the other, respecting the prospective relevance of the Equal Protection Clause to instances of state legislative malapportionment.

It is true, of course, that some of the ratifying states may have been as malapportioned in 1866 as they were in 1963, although the futility of relying upon local political processes as a corrective was by no means so clear then as it has since become. It is even likely, by way of conjecture, that had the subject been discussed there might have been a disavowal of an intention to apply the Equal Protection Clause to malapportionment, at least at that time. The historical record in this respect, however, is no more controlling than it has been elsewhere: hypothetical answers to hypothetical questions never actually entertained at the time would be a most dubious basis for expounding the content of "equal protection" one hundred years later.

The application of the Equal Protection Clause to practices of state legislative malapportionment is unexceptionable in terms of the inconclusive legislative history of the Fourteenth Amendment. It is neither precluded by any remedy exclusively provided in $\S 2$ nor at variance with the language or any original and declared limitation on the Equal Protection Clause itself. Under these circumstances, it is difficult to believe that the decision in Reynolds $v$. Sims should have been foreclosed solely on the strength of the legislative history of the Fourteenth Amendment. At the very most, Mr. Justice Harlan's historical review in Reynolds v. Sims raises a fair question respecting the historical integrity of the Court's willingness to entertain Carrigan v. Rash strictly as an equal protection case, since here state voter qualifications were themselves in issue. To that limited extent, it may be said that Mr. Justice Harlan wrote the "right" dissent in the "wrong" case. Even here, however, the dissent rests upon an extremely doubtful view of the original understanding. 


\section{APPENDIX}

\section{Chronology of Fourteenth Amendment Bills}

\begin{tabular}{|c|c|c|c|}
\hline Date & $\begin{array}{c}\text { H.R. No. } 51 \\
\text { Antecedent of } \$ 2\end{array}$ & $\begin{array}{c}\text { H.R. No. } 63 \\
\text { Antecedent of } 81\end{array}$ & $\begin{array}{c}\text { S. No. } 61 \\
\text { Civil Rights Act }\end{array}$ \\
\hline $\begin{array}{l}\text { Jan. } 5 \ldots \ldots \\
\text { Jan. } 22 \ldots \ldots \\
\text { Jan. } 31 \ldots \ldots \\
\text { Feb. } 2 \ldots \ldots \\
\text { Feb. } 13 \ldots \ldots \\
\text { Mar. } 9 \ldots \\
\text { Mar. } 13 \ldots \\
\text { Mar. } 15 \ldots \\
\text { Mar. } 27 \ldots\end{array}$ & $\begin{array}{l}\text { Introduced in } \\
\text { House } \\
\text { Passed House } \\
\text { Inadequate vote of } \\
\text { approval in Sen- } \\
\text { ate (25-22) } \\
\text { Reopened }\end{array}$ & $\begin{array}{l}\text { Introduced in } \\
\text { House }\end{array}$ & $\begin{array}{l} \\
\text { Passed House } \\
\text { with amend- } \\
\text { ment } \\
\text { Senate concurs in } \\
\text { amendment } \\
\text { Returned to } \\
\text { Congress with } \\
\text { veto } \\
\text { Repassed in Sen- } \\
\text { ate } \\
\text { Repassed in } \\
\text { House }\end{array}$ \\
\hline & \multicolumn{3}{|c|}{ H.R. No. 127: Consolidated Fourteenth Amendment } \\
\hline $\begin{array}{l}\text { Apr. } 30 \ldots \\
\text { May } 10 \ldots \\
\text { June } 8 \ldots \\
\text { June } 13 \ldots\end{array}$ & \multicolumn{3}{|c|}{$\begin{array}{l}\text { Introduced in House and Senate } \\
\text { Passed in House } \\
\text { Passed with amendments in Senate } \\
\text { House concurs in Senate amendment }\end{array}$} \\
\hline
\end{tabular}

